\title{
The experiences of older adults with a diagnosed functional mental illness, their carers and their healthcare professionals in relation to mental health service delivery: an integrative review.
}

WELLS, J., KENNEDY, C., BAIN, H., LEE, S.H.

This is the peer reviewed version of the following article: WELLS, J., KENNEDY, C., BAIN, H. and LEE, S.H. 2020. The experiences of older adults with a diagnosed functional mental illness, their carers and their healthcare professionals in relation to mental health service delivery: an integrative review. Journal of clinical nursing, 29(1-2), pages 31-52, which has been published in final form at https://doi.org/10.1111/jocn.15067. This article may be used for non-commercial purposes in accordance with Wiley Terms and Conditions for Use of Self-Archived Versions. 
The experiences of older adults with a diagnosed functional mental illness, their carers and their healthcare professionals in relation to mental health service delivery: an integrative review

Julia Wells PhD student MA (merit) BA Dip HEN mental health nursing RMN, School of Nursing and Midwifery, Robert Gordon University, Aberdeen, Scotland Catriona Kennedy PhD BA (Hons) DN RNT RN, School of Nursing and Midwifery, Robert Gordon University, Aberdeen, Scotland

Heather Bain EdD Pg Cert HELT, FHEA, BA Community Health, Dip DN RGN, School of Nursing and Midwifery, Robert Gordon University, Aberdeen, Scotland

Siew Hwa Lee PhD MPHE BSC (Hons) FHEA RN, School of Nursing and Midwifery, Robert Gordon University, Aberdeen, Scotland

\section{Correspondence:}

Julia Wells

School of Nursing and Midwifery

Robert Gordon University

Aberdeen

Scotland

United Kingdom

E-mail: j.wells1@rgu.ac.uk

https://orcid.org/0000-0002-8518-3955 


\begin{abstract}
Aims and objectives: The aims of this integrative review were to a) analyse the experiences of older people with a diagnosed functional mental illness and their carers in relation to mental health service delivery and b) analyse the experiences of health and social care professionals who care for and treat older people who have a diagnosed functional mental illness.
\end{abstract}

Background: The prevalence of functional mental illness in older adults is notable but to date has received less research attention than dementia. Older adults with functional mental illness have life expectancy of up to twenty years less than the rest of the population. Therefore, the experiences of older adults with functional mental illness, their carers and healthcare professionals, in relation to mental health services, need further exploration.

Design: Integrative literature review.

Methods: A five-stage process was informed by Whittemore and Knafl. MeSH was used. Keyword searches of MEDLINE, CINAHL, Cochrane Library, PsycINFO, EMBASE, and AMED were conducted between January 2000 and October 2017. Titles were screened, and data were extracted manually and analysed using narrative synthesis. The PRISMA checklist was used.

Results: A total of 342 articles were deemed potentially relevant to this review. Once inclusion and exclusion criteria were applied, 28 articles were included. The literature presented an overarching theme 'determinants influencing older people with functional mental illness use of services'. The overarching theme is supported by two main themes: inevitable consequences of ageing and variations of the availability of healthcare services for older people with functional mental illness. 
Conclusion: Several determinants influence use of services by older people with functional mental illness. Older people with functional mental illness often perceived they did not have a mental health need. Within the literature, there was little acknowledgement of the experiences of older people with functional mental illness regarding their support needs.

Relevance to clinical practice: This integrative review has highlighted that some older people with functional mental illness do not seek mental health support because they believe that functional mental illness is an inevitable consequence of ageing; this is mirrored at times by healthcare professionals and carers. In addition to this finding, different views prevail regarding the impact that ageless and age-defined mental health service delivery models have on the needs of older people with functional mental illness. Further research is required to understand these findings.

\section{What does this paper contribute to the wider global clinical community?}

- Different views prevail regarding the impact that ageless or age-defined mental health delivery models for older adults with functional mental illness and therefore their impact upon need in this population group is ambiguous.

- This review illuminated that there are gaps in service delivery models and health and social care professionals' knowledge to support a holistic approach to health in older adults with functional mental illness.

- Older adults with functional mental illness may not perceive that they require support with their mental health, thus impacting on what support they access.

Keywords: older adults, mental illness, severe mental illness, functional mental illness, carers/families, healthcare professionals, mental health services. 


\section{Introduction}

In many healthcare systems around the world, mental illness in older-adult mental health services is classified into two main groups: organic or functional mental illness (FMI) (Collier 2008). Organic mental illness is defined as a mental illness caused by a physical change in brain tissue; these changes are often degenerative in nature, as in dementia (Logsdon 2018). In contrast, FMI is not degenerative in nature and encompasses illnesses such as depression, bipolar disorder, schizophrenia, and anxiety disorders (Collier 2008).

Worldwide, care and support for older people with FMI is primarily provided by informal carers such as spouses, family and friends (Broady \& Stone 2015). However, caregiving can have a negative impact on carers' own psychological and physical health (McCann et al. 2016). This negative impact, termed 'carer burden,' can be exacerbated by needing to be available to the older person with FMI to provide support, monitor symptoms and navigate professional support when required, often at the cost of the carer's own health (Broady \& Stone 2015). Carers of people with FMI are reported to have a higher prevalence of depression (including feelings of guilt and sadness) in comparison to those who do not provide care for people with FMI (McCann et al. 2016). Additionally, carers can experience feelings of loss and grief when caring for a person who was once independent in their role as the carer's spouse or parent (McCann et al. 2016). Meeting the needs of older people with FMI is therefore important and significant.

Broady \& Stone's (2015) study in New Zealand illustrated that the caring role can also be a positive intervention, with carers describing experiences of love, support, fulfilment and a sense of achievement (Broady \& Stone 2015). Others describe how caring for a family member can provide a sense of purpose and fulfilment. Furthermore, providing care as a 
family member - as opposed to hiring a stranger - may be comforting, as highlighted by McCann et al. (2015) in their Australian study. A number of factors contribute to informal carers being the biggest source of care provision; these include an ageing population, increasing costs of care and limited availability of services.

Worldwide, the ageing population is growing; in 2017, the global population of people aged over 60 was 382 million, and this figure is projected to almost double by 2050 (World Data Bank 2015). This ageing population presents a major challenge to health and social care services, now and in the coming decades (Anderson 2011). The growth of the ageing population seems to suggest that the incidence of FMI in older people will also increase, and for some illnesses, such as depression and anxiety, it certainly will. However, a dichotomy currently exists, as some older people with FMI (those with severe and enduring mental illness such as schizophrenia and bi-polar disorder) have an expected life expectancy of up to twenty years shorter than the general population (WHO 2018).

Worldwide, the number of people living with FMI in the general population is significant, and while this number is lower among older adults than younger ones, it is still notable and projected to increase in incidence (Anderson 2011). Currently, FMI is estimated to affect one in four people in the general adult population and $15 \%$ of people aged over sixty worldwide (WHO 2018). Globally, it is predicted that depression will be the leading cause of illness burden in older people by 2020 and will affect one in five people over 60, with severe depression expected to increase by $49 \%$ by 2026 (Royal College of Psychiatrists 2018). Schizophrenia is estimated to affect $0.5 \%$ of the world's population aged over sixty (Loebach-Wetherhell \& Jeste 2017), and anxiety disorders are reported to affect one in 
twenty older people (Royal College of Psychiatrists 2018). As people with FMI become older, they are also more likely to develop a physical illness (Government UK 2018).

Older people with FMI have complex needs. In addition to coping with specific symptoms relating to their FMI (including delusions, hallucinations, and agitation), they are also likely to develop a physical comorbidity (Government UK 2018). Reasons for this might be that some older adults with FMI are more likely to have experienced years of economic deprivation, poor diet, significant alcohol intake, and heavy smoking (Government UK 2018), all of which are contributory factors to their poor life expectancy and place this population at increased risk of diabetes, stroke, cardiac problems and vascular illness (Government UK 2018).

In older adults with FMI, physical and mental health needs impact one another and rarely appear singularly (WHO 2018). Generally, the physical health needs of an older adult present as general functional decline, accompanied by pain, physical frailty, sensory impairment and multiple medication use (WHO 2018). These complex needs may inhibit the ability of an older person to seek appropriate support. Furthermore, the complexity of both physical and mental health needs poses a potential challenge to healthcare professionals who may work in silos, focusing on either physical or mental health (Hilton 2012). This siloing may contribute to a potential lack of the skills and knowledge needed to holistically meet the needs of this population.

Care and treatment of older people with FMI can be offered across a spectrum of services, depending on the severity of the person's symptoms. While many older adults with mild symptoms of FMI will be managed by their physician, those with more severe and enduring 
symptoms, mainly psychosis or severe depression, are likely to need specialist mental health input in both hospital and community settings (Warner and Jenkinson 2013). Given the ageing population, increasing costs and limited services, care for older people with FMI worldwide is primarily provided by family members and other informal carers (Broady \& Stone 2015).

Globally, little attention is paid to older adults with FMI and their carers, leading to a large research gap (McCormack and Skatvedt 2017). In contrast, dementia has been a key priority in health and social care policy and in research internationally (Saad et al. 2016). In 2014, The Glasgow Declaration called for a European dementia strategy that led to many European countries producing their own strategies. In contrast, there are no specific clinical guidelines relating to older adults with FMI. Therefore, the emergence of different service delivery models for older people with FMI has evolved with minimal supporting evidence. Therefore, this review fills an important gap: exploring the experiences of older people with FMI, their carers and healthcare professionals in relation to mental health services

\section{Aims}

The aims of this integrative review were to a) analyse the experiences of older people with a diagnosed FMI and their carers in relation to mental health service delivery and b) analyse the experiences of health and social care professionals who care for and treat older people who have a diagnosed FMI.

Therefore, the following review questions were developed.

- What are the experiences of older people with FMI, their carers, and healthcare professionals providing mental health services? 
- How are the physical and mental health needs of older people with FMI, their carers, and healthcare professionals identified and met?

\section{Methods}

A review protocol was registered with the International Prospective Register for Systematic Reviews (PROSPERO) 2017 CRD42017080576

(https://www.crd.york.ac.uk/prospero/export_record_pdf.php)

\subsection{Design}

An integrative literature review was chosen because this approach encompasses diverse research designs, ensuring no research findings were excluded (Whittemore \& Knafl 2005). An integrative review can provide a holistic understanding of how older adults with FMI, their carers, and healthcare professionals experience mental health services. The methodological approach includes five stages described by Whittemore and Knafl (2005): (i) problem identification, (ii) literature search, (iii) data evaluation, (iv) data analysis, and (v) presentation.

\subsubsection{Literature search}

Search strategy

For the purpose of this integrative review, the focus was on FMI in older people (older than 65). Inclusion and exclusion criteria were applied (See Table One). Six international electronic databases were searched: MEDLINE, CINAHL, Cochrane Library, PsycINFO, EMBASE, AMED, and grey literature. Reference lists of included studies were scanned to identify articles that might be eligible for the review. MeSH and search terms were used (Table 2). The search was piloted in MEDLINE and adapted to other databases (Table 2). 
The early part of the millennium saw key legislative reviews and the introduction of new legislative acts that impacted this population group; therefore, the search was limited to the years 2000-2017. The articles included were published in English and were from Europe, New Zealand, Australasia, and North America. All articles were exported to Refworks, allowing duplicates to be documented and then deleted. The Preferred Reporting Items for Systematic Review and Meta-Analyses (PRISMA) guided the audit trail (PRISMA checklist: See Supplementary File 1) (Moher et al. 2009).

\section{Study selection}

Two reviewers (JW and SHL) screened the titles and abstracts independently. The reviewers used Rayyan QCRI software (2018), which allows the process of screening titles and abstracts to be 'blinded' to reviewers. Potential full texts were retrieved, assessed, and any doubts were discussed between the two reviewers. If agreement was not reached, then a third reviewer made the final decision (CK).

\subsubsection{Data evaluation and quality appraisal}

Data were extracted using a predetermined format. Key information was extracted: the author, year, country of study, type of study design, aims of the study, characteristics of participants, methods of data collection, key stakeholders' experiences in relation to mental health service delivery, and accessibility of mental health services for older people with FMI. Key findings were also documented. Data extraction forms were used to produce summary Table 3 .

\section{Quality appraisal of included studies}


Qualitative and quantitative articles were appraised for quality using the recognised Critical Appraisal Skills Programme tools (CASP 2017), and cross-sectional studies were appraised using the NHLBI (National Heart Lung Blood Institute) appraisal tool (2018). No mixed method studies were yielded in this review. Appraisal of literature in this review was not intended to exclude articles on the basis of quality but rather to draw on all available evidence.

\subsubsection{Data analysis}

Whittemore and Knafl (2005) suggest that data analysis be ordered, coded, categorised, and summarised to allow the drawing of conclusions regarding the research problem. Therefore, the narrative synthesis framework by Popay et al. (2006) was used to theme data in this review; this approach was chosen because it can synthesise multiple studies by focusing on words and text (Popay et al. 2006). Using the framework of narrative synthesis, key findings were tabulated from a summary table (Table 3). Next, key findings were coded and grouped into similar concepts by the PhD student. These concepts were then checked and refined via reflective discussion at supervision, thus ensuring the validity and reliability of results by minimising any potential bias of the reviewers. This process ultimately led to the development of one overarching theme and two main themes.

\section{Results}

\section{Search results}

The search yielded a total of 2,556 articles. In total, 741 of these articles were duplicates, resulting in 1,815 titles and abstracts being screened. A total of 342 articles (PRISMA flow chart: Figure 1) were identified as potentially relevant to the literature review question. The inclusion and exclusion criteria were then applied to the 342 articles 
remaining; this revealed 27 articles that were considered relevant for this review. One additional appropriate paper (Bawn et al. 2007) was revealed by screening the reference lists of included articles. No articles were included from the grey literature. Therefore, 28 studies were included in this review.

\section{Study characteristics}

There were 23 quantitative studies and five qualitative studies. Thirteen studies were conducted in the USA $(n=13)$, with the rest conducted in the UK $(n=5)$, Canada $(n=3)$, Australia ( $n=2)$, Holland ( $n=2)$, Ireland $(n=1)$, Norway $(n=1)$ and New Zealand $(n=1)$.

\section{Study quality}

The overall quality of the included studies appeared to be moderate. Of the five qualitative studies, four did not discuss the relationship between the researcher and participants, and in two studies, ethical considerations were not documented. Of the five cross-sectional studies, all aspects of the appraisal tool were met.

\subsection{Themes}

Thematic analysis of the literature illuminated an overarching theme: 'determinants influencing the use of services among older people with FMI'. This overarching theme illustrates a number of factors that influence this population's decisions whether to use mental health services. The theme 'inevitable consequence of ageing' highlights that older adults with FMI often do not access mental health services because they perceived their FMI needs as related to the ageing process. This perspective was shared by family carers and healthcare professionals. Other factors, including stigma and ageism, were also found to influence the use of services by older adults with FMI. 
The second theme, 'variations in availability of healthcare services for older people with FMI,' highlights that the cost and availability of services may influence older people to seek support for their mental health needs. This theme also highlighted that service delivery models may influence a healthcare professional's decision-making when offering support.

\subsubsection{Inevitable consequences of ageing}

Seventeen studies (eleven quantitative and six qualitative) supported the theme 'inevitable consequences of ageing'. These studies were from the United States $(n=8)$, Australia $(n=2)$, Holland ( $n=2)$, the United Kingdom $(n=1)$, Ireland $(n=1)$, New Zealand $(n=1)$, Canada $(n=1)$ and Norway $(n=1)$.

\subsubsection{Perceived need}

The literature yielded in this review illustrated that perceived need was a factor influencing what support and mental health services older people with FMI received. Nine studies from two countries (USA $n=7$; Holland $n=2$ ) illustrated that older people with FMI and their healthcare professionals share the perception that mental health needs decline as people age. Mackenzie et al. (2010), in their quantitative study, demonstrated that $47.1 \%$ of older people ( $n=3017)$ were less likely to perceive that they had a mental health need compared to younger people. Crabb and Hunsley (2006) demonstrated that low perceived need in older people correlated with lower use of mental health services, with those aged over 65 $(\mathrm{N}=23,364)$ found to be half as likely to seek mental health support compared to those aged $45-64(\mathrm{~N}=35,958)$.

Cummings (2009), in a study of $(n=75)$ older people, found that $70 \%$ felt they did not receive the support they required for their mental health and therefore had unmet needs in relation to 
chronic illness, functional disability (with impairment in four or more activities of daily living), and decreased social support, including home care. Houtjes et al. (2011) suggest this situation occurs because mental health needs are not always discussed by healthcare professionals during assessments in specialist services. This finding was corroborated by Muir et al. (2014), who revealed that older people and their carers shared the perception that healthcare professionals believed older people's mental illnesses were due to dementia and therefore overlooked.

Several studies revealed that physicians can see depression as an inevitable consequence of the ageing process (Holvast et al. 2012; Arean et al. 2007; Palinkas et al. 2007; Muir et al. 2014). Arean et al. (2007) conducted a randomised controlled trial of older people $(n=1801)$, examining older adults' use of mental healthcare. Within this study, collaborative care for depression was compared with the usual care for depression in primary care. This study illustrated that physicians generally did not routinely screen for depression in older adults, which resulted in under-treatment of depressive symptoms. Muir et al. (2014) demonstrated that healthcare professionals focused more on the physical needs of older people rather than their mental health needs.

Another factor in the reluctance of older people to seek attention for FMI was that healthcare professionals did not always recognise that older people with FMI required mental health support, even when the healthcare professional was a specialist mental healthcare professional (psychiatrist, community mental health nurse, or psychologist) (Houtjes et al. 2011). 
Two studies revealed that older people with FMI often do not recognise that they have a mental health need (Muir et al. 2014; Mackenzie et al. 2010). Muir et al. (2014) explored health and social care barriers for older people with mental health issues in rural Australia. These studies do not specify why older people with FMI often fail to recognise that they need support. However, Crabb and Hunsley (2006) propose that older people with FMI often felt that younger people were more in need of services than they were.

Several studies have identified that the use of mental health services decreases as people age (Mackenzie 2008; Crabb \& Hunsley 2006). Holvast et al. (2012) found that people aged over 65 were less likely to seek mental health services than younger people because they utilised their social support networks instead. Mackenzie et al.'s (2008) study revealed similar findings; they examined the variables between older people and younger people who sought mental health services and found that people aged over 75 were four times less likely to seek mental health services than those aged between 65 and 74 .

In contrast, two studies found that older people were more likely to use mental health services than their younger counterparts. Mackenzie et al. (2008) surveyed adults in community living $(\mathrm{N}=5692)$ on the attitudes of younger people compared to older people $(\mathrm{N}=1341)$ and their use of mental health services. They found that $80 \%$ of older adults were more likely than younger people to access mental health services. Another study by Nelson and Park (2006) found that older people had fewer unmet mental health needs and experienced fewer barriers when accessing services compared to younger people. This study demonstrated that most people who experienced unmet needs did so because they preferred to manage their needs themselves. 


\subsubsection{Stigma}

The literature included in this review highlighted that stigma influenced the decision making of older people with FMIs when they considered seeking mental health support or services. Three American studies (Byers et al. 2012; Crabb \& Hunsley 2006; Mackenzie 2006) illustrated that older people with FMI were more forthcoming in seeking support for their FMI if they had a comorbid physical illness. Crabb and Hunsley (2006) revealed that the tangible aspects of physical ill health were often easier for older people with FMI to recognise (examples include diabetes, chronic cardiovascular disorders and chronic pain). However, the study failed to address whether it was a physical or mental health condition that propelled them to seek support from a physician or if the mental health issue was secondary to their physical illness.

Four studies from a range of countries (Canada $n=1$; Holland $n=1$; USA; $n=2$ ) found that older people with FMI preferred to see their physician rather than specialist services about their mental health, particularly about psychological distress (Preville et al. 2009; Holvast et al. 2009; Crabb and Hunsley 2006; Mackenzie et al. 2010). Older people with FMI found it easier to confide in their physician about their mental health needs compared to a mental healthcare professional; this decision largely stemmed from the stigma that older people projected onto mental health services (Mackenzie 2010).

Byers et al.'s (2012) study found that physical health conditions correlated with higher use of mental health services in older people. Crabb and Hunsley (2006) found that $95 \%$ of older people seeking support from mental health services were found to have co-existing medical comorbidity. People who experienced cardiovascular illness, chronic pain or any medical condition were far more likely to seek mental health support because they had the tangible 
reason of physical ill health accompanying their less-tangible mental health needs (Byers et al. 2012; Crabb \& Hunsley 2006).

Several studies highlighted that stigma and ageism were determinants of the usage of mental health support in older people with FMI (Byers et al. 2016; Muir et al. 2014; Palinkas et al. 2007; McCormack \& Skatvedt 2017). Byers et al.'s (2012) study revealed that some older people with FMI reported being embarrassed to discuss their mental health needs and therefore did not access mental health services. Furthermore, some older people with FMI did not access mental health services out of concern that their friends might find out (Muir et al. 2014). Muir et al. (2014) found that access to mental health services can be associated with stigma; this was sometimes perceived as a generational issue, with an apparent lack of understanding regarding mental health in the older age group.

A number of studies found that older people with FMI want to remain self-sufficient, independent, and self-reliant as well as be seen as resilient (Byers et al. 2012; Crabb and Hunsley 2006; Muir et al. 2014). In addition, older people took pride in their ability to manage and wanted to be perceived by others as stoic (Muir et al. 2014). However, this sense of pride had a negative impact; Byers et al.'s (2012) study found that $70 \%$ of older people were embarrassed to acknowledge that they needed help. Older men in particular viewed seeking mental health support as a sign of weakness (Muir et al. 2014).

Another barrier to seeking support could be that people of some ethnic origins are less likely to seek help for their mental health needs (Byers et al. 2016); one explanation is that they might be uncomfortable discussing mental health needs, which they view as personal problems, with healthcare professionals. In contrast, Sarkin et al. (2015) found that older 
people $(n=1237)$ felt less stigmatised than younger people and were therefore more likely to access mental health services. That study focused on people living in San Diego, which may offer some explanation for these diametric findings. However, it was the only paper to use a validated tool (the stigma scale) when assessing stigma.

\subsubsection{Ageism}

This review illustrated that ageist attitudes, or perceived ageist attitudes, from health and social care professionals influenced the decisions of older people with FMIs regarding accessing mental health services or mental health support. Some older people with FMI perceived ageist attitudes among healthcare professionals and reported that they had experienced ageism (Palinkas et al. 2007; McCormack \& Skatvedt 2017). Ageism is defined by Palinkas et al. (2007) as negative attitudes towards older people from service providers, and it has influenced older people's desire to seek mental health support (Palinkas et al. 2007). Healthcare professionals also reported a lack of available mental health services appropriate for older people (Bawn et al. 2007; Palinkas et al. 2007; Muir et al. 2014). Muir et al. (2014) suggest that services for older people are set up to meet physical needs and do not focus on mental health. Bawn et al. (2007), in a UK survey, reported that there is less financial investment in older adult services compared to ageless services, meaning there are fewer services available to older people with FMI.

A study by McCormack and Skatvedt (2017) explored the experiences of older people with FMI who received mental health services and had carers living at home. This study highlighted that some family carers perceived that their loved ones did not always receive the standard of mental healthcare that they expected from mental health nurses. In a qualitative study, McCann et al. (2016) aimed to understand the lived experiences of carers of older 
people with FMI (aged over $60(n=30)$ ); it was reported that older people and their carers expected mutual respect with their healthcare professionals, which they did not always perceive.

\subsubsection{Impact of caring}

The literature gathered in this review highlighted that older people with FMI rely heavily upon family carers for mental health support and that family carers play an important role. However, playing that role heavily impacted the health of family carers. Cummings et al. (2009) found that $75 \%$ of older people with FMI had to rely heavily on their family members for support with their physical needs and highlighted that family carers are often a main and essential source of care for older people with FMI. One study illustrated that family members were expected by society to support their elderly relatives with their mental health needs (Broady \& Stone 2015). This expectation was heightened if the carer was a spouse, as support was considered to be part of the marital role (Molyneux et al. 2008). Some family carers expressed that healthcare professionals were unaware of the impact that their caring role had on their own health (Muir et al. 2014). Other family carers reported that their caring role impacted their own mental and physical health; some had depressive symptoms that increased the need for prescribed medication as a means to cope with their caring role (Broady \& Stone 2015). Healthcare professionals often focused on the needs of the older person with FMI and did not consider the carer's needs and how the caring role affected their health (Muir et al. 2014).

Evidence gathered under this theme identified several factors considered to be inevitable consequences of ageing that impacted the use of services by older people with FMI. For example, older people with FMI often did not perceive that they had a mental health need and 
strove to remain independent in their daily living, and men in particular viewed support for mental health as a sign of weakness. Stigma and ageist attitudes were a deterrent to seeking support among older people with FMI. Older people found it easier to confide in their physicians about their mental health, using the guise of a physical health need. However, support from physicians was not always available, as many viewed FMI as an inevitable consequence of ageing. Finally, there was an identified societal expectation that older people would receive support for mental health from their family, particularly a spouse. The caring role often impacted the health of the caregiver, who might receive little support when performing their caring role.

\subsubsection{Variations in the availability of healthcare services for older people}

\section{with FMI.}

Eighteen papers relating to this theme were identified: fifteen were quantitative and three qualitative. The studies were conducted in the United States $(n=10), \mathrm{UK}(n=3)$, Canada $(n=2)$, New Zealand $(n=1)$, Australia $(n=1)$ and Norway $(n=1)$.

\subsubsection{Affordability}

This review found that the affordability of mental health services influenced the decision to seek support not only by older people with FMIs but also by their family carers. Four studies from two countries reported that the cost of mental health services was an influencing factor in service usage by older people with FMI (USA $n=3$; New Zealand $n=1$ ). Two studies found that older people were often unable to afford medical insurance, which in turn affected the mental health services they could access (Karlin \& Norris 2006; Broady \& Stone 2015). 
An American survey conducted by Karlin and Norris (2016) of people aged over $18(n=12$, $810)$ revealed that only $5 \%$ of older adults accessed mental health services. The authors attributed this finding to older people often being financially restricted, lacking healthcare insurance and being unable to fund the services they required. This finding is corroborated by Palinkas et al.'s (2007) and ( $n=16)$ and Robb et al.'s (2003) studies of older people $(n=474)$, which also found that older people are less likely than younger people to have healthcare insurance.

Broady and Stone (2015) discovered that financial restrictions affected not only older people with FMI but also their carers. That study demonstrated that only one in four carers accessed the support they need to effectively deliver their caring role. Carers' decisions to access services were affected by the cost implications, with many not having medical insurance due to reduced income from being retired. Furthermore, the caring role itself was time consuming, and carers often simply did not have time to access services because their time was occupied with caring for their family member (Broady \& Stone 2015).

\subsubsection{Accessibility}

The literature analysed in this review highlighted that a number of issues affected the accessibility of mental health services and their use by older people with FMI. One such issue was poor knowledge regarding available services and referrals to mental health services by a physician. Two studies from the United States found that accessing mental health services was more challenging for older adults with FMI compared to younger people, who are more adept at identifying their needs (Byers et al. 2012; Mackenzie et al. 2010), as, according to Byers et al. (2012), older people received insufficient information about mental health services. This finding was also highlighted by Robb et al. (2003), who discovered that older 
adults were found to be less confident in their knowledge about the services available to them in comparison to their younger counterparts, and this was a barrier to accessing support.

Older people with FMI also faced challenges in accessing mental health services, as they often found they had to be referred by their physicians to specialist mental health services, which they perceived as a barrier to accessing specialist support (Muir et al. 2014). However, in primary care services that had an integrated mental healthcare professional (such as a Community Mental Health Nurse or Psychologist), the experience for the older person was reported to be more positive because these healthcare professionals would assess for FMI and make referrals to the appropriate specialist services (Arean et al. 2007). Another barrier to accessing specialist mental health services, identified in Australia, was that older people with FMI felt that some local mental health services were unable to meet their mental health needs because they were already stretched and at full capacity (Muir et al. 2014). With contrasting findings, a study by Nelson and Park (2006) examined unmet need in Ontario in people aged $65+(n=2752)$ and in people aged 15-64 $(n=10,432)$; they report that older people have fewer unmet needs than younger people: older people accessed support, whereas younger people reported challenges around the availability of services (professionals unavailable in area, professionals unavailable when required and waiting times being too long).

\subsubsection{Availability}

This review illustrated that the availability of mental health services affected their use by older people with FMI. Factors influencing the availability of services related to where people lived and models of care for older people with FMI. Two studies highlighted that the availability of community support was dependent on where an individual lived (Preville et al. 2009; Karlin \& Norris 2006); people who lived in metropolitan areas were far less likely to 
seek mental health support from services in comparison to those who lived in metropolitan urban/ rural areas, as those living in metropolitan areas had more social support (Karlin \& Norris 2006). Furthermore, older people with FMI who lived with a spouse were far less likely to access support than older people who lived alone (Preville et al. 2009); however, the study offered no explanation for its findings.

A study by Simning et al. (2010) of older people $(n=378)$ explored the use of a dedicated depression care management team in primary care. The study revealed that people who were distressed by their FMI symptoms were far more likely to see a mental healthcare professional. Another model of mental healthcare explored was assertive outreach (where a community mental health team will provide intensive support to a person who is acutely unwell in the community). This model was found to be less favourable to carers who lived with the person with FMI, who experienced more carer burden with this model of care (Fulford \& Farhill 2001).

This review highlighted that different models of hospital care exist, and some mental health services are ageless in contrast to others that are age-defined (where a person is automatically transferred to an older person's service at 65) (Abdul-Hamid et al. 2016). Abdul- Hamid et al. (2016) undertook a UK-cross-sectional survey of 74 older people with FMI. The study aimed to compare the unmet need of older adults with FMI who were cared for in age-defined and ageless services. They concluded that older people with FMI who were cared for in ageless services were found to have a significant unmet need in relation to medication management, domestic life, and transport issues. Abdul- Hamid et al.'s (2016) findings are supported by Palinkas et al.'s 2017 study and a study by Morrow-Howell et al. (2000), who focused on the needs of ( $n=169)$ older people with depression post-acute-care, across psychosocial, medical, 
functional and psychiatric needs. That study revealed that healthcare professionals working in an ageless service lacked the knowledge and skills to assess older people with FMI with regard to physical comorbidities.

By contrast, two UK studies concluded that ageless services were better equipped to meet the needs of older people with FMI. A survey by Bawn et al. (2007) of mental healthcare professionals $(n=55)$ revealed that age-defined mental health services have fewer multidisciplinary provisions than ageless services. Another UK quantitative study of older people with FMI ( $n=58)$ conducted by McNulty et al. (2003) aimed to measure the care needs of people aged over 65 with schizophrenia using a standardised tool. That study reports that when older adults were transferred to age-defined services, there was an increase in their unmet clinical and social needs (psychotic symptoms, financial needs, and social life).

Older adults with FMI who live in care homes also experienced challenges relating to their mental health needs (McNulty et al. 2003). Clancy and Baldwin's (2008) UK, comparative study of older people with FMI (n=23) adds weight to McNulty et al.'s (2003) contentions that older adults with schizophrenia in care homes have more concomitants and higher needs in relation to their activities of daily living in comparison to those living in their own homes. These needs were thought to be related to the negative symptoms (apathy, social withdrawal, lack of emotion) of the illness and the high prevalence of physical comorbidity. However, Clancy and Baldwin (2008) do not elaborate on which physical comorbidities participants in this study actually had. In this case, the needs of older adults with FMI were overshadowed by the needs of their counterparts who had dementia, and care-home staff were better trained to care for the latter (McNulty et al. 2003; Anderson et al. 2000). 
This review has illustrated that there are a number of variations in the availability of healthcare services, influencing the use of services by older people with FMI. In countries where health services are not free, cost was identified as a significant determinant of the use of services. However, the evidence suggests that service delivery models have an impact on the unmet needs of older people with FMI, with two studies concluding that ageless services reduce unmet needs. Some of the barriers to accessing mental health support were related to the referral process to specialist mental health services, variations in community support, and service delivery models. In care homes, healthcare professionals were found to have more knowledge surrounding dementia, which resulted in symptoms of FMI in older people being overlooked. This review has identified a gap in current research exploring the experiences of older people with FMI regarding support and whether the services available meet the needs of this population. Furthermore, little is known about what influences health and social care professionals' decisions to provide support for older people with FMI. Finally, this review revealed that few studies have explored the experiences of family members who care for older people with FMI.

\section{Discussion}

The aim of this integrative review was to synthesise the findings of all available studies that explored the perceived experiences of older adults with FMI, their family carers, and healthcare professionals in mental health service delivery. The review yielded 28 studies that have been summarised into one overarching theme, 'determinants influencing the use of services by older adults with FMI', and two main themes: 'The inevitable consequences of ageing' (which included stigma and ageism) and 'Variations in availability of healthcare services for older people with FMI'. The relevance of these findings is significant and has implications for policy, education and future research. 


\subsection{Policy implications}

Findings from this review highlighted that older people with FMI are less likely to access mental health services than younger people (Byers et al. 2012; Mackenzie et al. 2010; Robb et al. 2003). This review also illustrated that there may be a hidden population of older people with FMI who are invisible to mental health service providers (Holvast et al. 2012; Mackenzie 2008). Thus, government and health surveillance agencies need to collect accurate data on the prevalence of this population group as it correlates with the use of mental health services. These data must be dissected, analysed and interpreted nationally by policy makers and service providers to ensure equitable mental healthcare provision for this population group in the UK (Anderson 2011).

This review also illustrated that while different models of service delivery exist for older people with FMI, these models do not always embrace a holistic approach to care. Internationally, there is inconsistency in service delivery models for people with mental illness (WHO 2018), with an assortment of ageless and age-defined services. For older adults with FMI within the European Union, only six countries (UK, Switzerland, Romania, Slovakia, Ireland and Czech Republic) recognise Older Adult Mental Health services as a subspecialty of psychiatry. Across continental Europe, care and treatment are predominantly delivered in ageless services for people with mental illness across hospital and community settings by healthcare professionals with generalist mental health knowledge.

Different views prevail as to whether ageless mental health services should exist (Union of European Medical Specialties 2013) or whether age-defined services should be offered to all by staff who are equipped to deal with physical complexities, such as pain and physical 
frailty, alongside FMI (Abdul-Hamid et al. 2016). There is consensus that community services are the desired model of delivery for mental health services (Union of European Medical Specialties 2013).

Warner and Jenkinson (2013) defend the need for specialist older adult mental health services and surveyed 76 OAMH services in the UK; $52 \%$ of respondents viewed the erosion of specialist older adult mental health services as detrimental to older people with FMI due to the social, psychological and physiological complexities that accompany old age. In contrast, Bawn et al. (2007) suggest that older people with FMI are disadvantaged by specialist OAMH services due to a lack of investment in such services. Anderson (2011) suggests that providing older people with the same level of mental health services as younger people, based on need, would cost approximately $£ 2$ billion a year, which is one-seventh of the NHS budget. With an ageing population, this level of spending is not achievable. Therefore, new models of mental health service delivery for older people with FMI need to be urgently explored by service commissioners and providers to ensure that models of care meet the needs of the population in an equitable, achievable way.

\subsection{Education implications}

This integrative review has highlighted that changes are needed in the education of health and social care professionals in order to develop a holistic approach to treating older people with FMI (Abdul-Hamid et al. 2016; Palinkas et al. 2017; Morrow-Howell 2000). Support is therefore needed from educational institutes and healthcare systems to help health and social care professionals understand and deliver a more holistic model of care that focuses on both the physical and mental health needs of older people (Abdul-Hamid et al. 2016; Palinkas et al. 2017; Morrow-Howell 2000). This integrative review demonstrated that some general 
physicians lack a holistic approach when treating older people, as there is only a $50 \%$ recognition rate of depression in this population group (Holvast et al. 2012). The impact is that older people with FMI often have unmet physical and mental health needs (Cummings 2009). Inadequate detection and treatment of FMI in older people represents a serious threat to this population's quality of life and functioning (Crabb and Hunsley 2006). Among health and social care professionals and general practitioners, improved knowledge of screening and assessment for FMI in older people would improve the diagnosis of FMI and in turn facilitate support (Arean et al. 2007; Muir et al. 2014).

\subsection{Research implications}

Most studies in this integrative review used a quantitative approach $(n=23)$. Few authors have explored the experiences of older people with FMI, their carers and healthcare professionals in the in-depth way that qualitative research fosters. Therefore, regarding mental health services, there is a gap in current research exploring the views and perspectives of older people with FMI, their carers and healthcare professionals. It is argued that in healthcare, it is important to understand diverse perspectives in order to shape service delivery in a way that is optimal for recipients (Brookes 2007). Further research using a case study approach is needed to gain an in-depth understanding of what determinants influence the use of mental health services by older people with FMI. In addition, there is a need to identify best practices in relation to models of care for older people with FMI.

\section{Limitations and strengths of the review}

The strengths of this integrative review are that it has yielded relevant international studies that reflect the experiences of older adults with FMI as well as their lay and professional 
carers in mental health service delivery. This review used a robust, transparent approach and involved at least two reviewers at all stages.

One limitation of this review is that the topic range is quite broad; therefore, synthesis of the literature was challenging, as the findings were general. In addition, the review did not consider health beliefs related to the ageing process or explore how the onset or duration of mental illness affected perceptions of and access to mental health services. Furthermore, many of the quantitative study designs of the included studies used surveys, with only one randomised controlled trial. Finally, studies published in foreign languages were excluded; therefore, vital information may have been missed.

\section{Conclusion}

Several determinants influence the use of mental health services by older adults with FMI.

Older people themselves consider FMI to be an inevitable consequence of ageing; this perception is mirrored by their carers and healthcare professionals. This assumption, in turn, influences the decision to seek support; likewise, it influences healthcare professionals' decision-making in offering mental health support.

In countries where services are not free, cost affected decisions about whether to access support. Other determinants of the use of services by older people with FMI were stigma and ageism. Older people with FMI reported that they experienced ageism from healthcare professionals, and they themselves stigmatised mental health problems. In the UK, a paradox exists in mental health service delivery models with the introduction of the Equality Act, which led to some mental health services adopting ageless services and others maintaining specialists in services for those over 65 . The introduction of this act has addressed issues of 
direct discrimination against older people but may inadvertently also be causing indirect discrimination (Warner and Jenkinson 2013).

This integrative review has highlighted that there is limited evidence exploring the experiences of older people with FMI with regard to support and whether the mental health services available meet their needs. Furthermore, little is known about what influences health and social care professionals' decisions to provide support for older people with FMI. Finally, this review revealed few studies exploring the experiences of family carers of older people with FMI. It is essential that these gaps in evidence be addressed to allow commissioners and health services to address the needs of this population group.

\section{Relevance to Clinical Practice}

This integrative review adds to the current body of knowledge by illustrating that there are a number of determinants influencing the use of mental health support by older people, who are not currently accessing the mental health services they require. However, there is a lack of current research informed by the perspectives of older people with FMI, their family carers and health and social care professionals. Therefore, further research is required and should use a qualitative approach to gain an in-depth understanding of what determinants influence the use of mental health services by older people with FMI. In addition, there is a need to identify best practices through further research in relation to models of care for older people with FMI. Finally, a holistic perspective should be used by health and social care professionals who assess older people to ensure that their mental and physical health needs are fully considered. 


\section{References}

Abdul-Hamid, W. K., Lewis-Cole, K., Holloway, F, \& Silverman, A, M. (2016). Comparison of how old age psychiatry and general adult psychiatry services meet the needs of elderly people with functional mental illness: Cross-sectional survey. British Journal of Psychiatry,207(5), 440443. doi: 10.1192/bjp.bp.114.145706.

Anderson, R. L., \& Lewis, D. A. (2000). Quality of life of persons with severe mental illness living in an intermediate care facility. Journal of Clinical Psychology, 56(4), 575-581. doi: 10.1002/(SICI)1097-4679(200004)56:4<575::AID-JCLP11>3.0.CO;2-S

Anderson, D., Banerjee, S., Barker, A., Connelley, P., Junaid, O., Series, H., \& Seymour, J. (2010). The need to tackle age discrimination in mental health: A compendium of evidence. The Royal College of Psychiatrists.

Anderson, D. (2011). Age discrimination in mental health services needs to be understood. The Psychiatrist.35, 1-4. doi: 10.1192/pb.bp.110.032094

Arean, P. A., Gum, A. M., Tang, L., \& Unutzer, J. (2007). Service use and outcomes among elderly persons with low incomes being treated for depression. Psychiatric Services, 58(8), 1057 1064. doi: $10.1176 /$ ps.2007.58.8.1057

Bawn, S., Benbow, S., Jolley, D., Kingston, P., Taylor, L. (2007).'Transitions': Graduating between general and old age psychiatry in England and Wales', Mental Health Journal Review, 21-26.

Broady, T, R., \& Stone, K. (2015). “How Can I Take a Break?” Coping Strategies and Support Needs of Mental Health Carers. Social Work in Mental Health, 13(4), 318-335. doi: $10.1080 / 15332985.2014 .955941$

Brookes, D. (2007). Understanding qualitative research and its value in healthcare. Nursing Times, 103(8), 32-33. doi: 10.1111/j.1365-2702.2008.02637.x

Byers, A. L., Arean, P. A., \& Yaffe. K. (2012). Low use of mental health services among older Americans with mood and anxiety disorders. Psychiatric Services, 63(1), 66-72. doi: 10.1176/appi.ps.201100121

Critical Appraisal Skills Programme (CASP). Qualitative Research Checklist. (2017). https://casp-uk.net/

Clancy, E., \& Baldwin, R. C. (2008). Comparison of older people with psychosis living in the community and in care homes. Psychiatric Bulletin, 32(5), 177-179. doi : 10.1192/pb.bp.107.017525

Collier, E. (2008). Historical development of psychiatric classification and mental illness. British Journal of Nursing, 17(14), 890-894. doi: 10.12968/bjon.2008.17.14.30655 
Crabb, R.., \& Hunsley, J. (2006). Utilization of Mental Health Care Services Among Older Adults With Depression. Journal of Clinical Psychology, 62(3), 299-312. doi: 10.1002/jclp.20231

Cummings, S. M. (2009). Treating older persons with severe mental illness in the community: impact of an interdisciplinary geriatric mental health team. Journal of Gerontological Social Work, 52(1), 17-31. doi: 10.1080/01634370802561919

DA, Q. (2019). Rayyan QCRI, the Systematic Reviews web app. [online] Rayyanprod.qcri.org. Available at: https://rayyan-prod.qcri.org/welcome [Accessed 18 Jan. 2019].

European Union of Medical Specialities. (2018). Uemspsychiatry.org. Retrieved from http://uemspsychiatry.org/wp-content/uploads/2014/03/2013Oct-Old-Age-Psych-in Europe.pdf

Fulford, M., \& Farhall, J. (2001). Hospital versus home care for the acutely mentally ill? Preferences of caregivers who have experienced both forms of service. The Australian and New Zealand Journal of Psychiatry, 35(5), 619-625. doi: 10.1046/j.1440-1614.2001.00915.x

Government UK . (2018). Research and analysis; severe mental illness (SMI) and physical health inequalities: briefing. Retrieved from https://www.gov.uk/government/publications/severemental-illness-smi-physical-health-inequalities/severe-mental-illness-and-physical-healthinequalities-briefing [Accessed 31/05/2019]

Hilton, C. (2010). Sans teeth, sans eyes, sans taste, sans everything:' resourcing mental health services for older people. Journal of the Royal society of Medicine. 135 (4), 146-150. doi:10.1258/jrsm.2012.120008

Holvast, F. et al. (2012). Determinants of receiving mental health care for depression in older adults. Journal of affective disorders, 143(1-3), 69-74. doi: 10.1016/j.jad.2012.05.029

Houtjes, W. et al. (2011). Unmet needs of outpatients with late-life depression; a comparison of patient, staff and carer perceptions. Journal of affective disorders, 134(1-3), pp. 242-248

Karlin, B.E., \& Norris, M.P. (2006). Public mental health care utilization by older adults. Administration and Policy in Mental Health and Mental Health Services Research, 33(6), 730736

Loebach-Wetherell, J., \& Jeste, D. V. (2017 ). Older Adults With Schizophrenia: Patients are living longer and gaining researchers attention. Elder Care. 3(2), 8-11. 29

Logsdon, A. (2018). Very Well Mind: Organic Mental Disorder Causes and Treatment. https://www.verywellmind.com/organic-mental-disorders-2162516 [Accessed 21/12/2018]

Mackenzie, C.S., Gekoski, W.L., \& Knox, V.J. (2006). Age, gender, and the underutilization of mental health services: The influence of help-seeking attitudes. Aging \& Mental Health, 10(6), 574-582. doi: 10.1080/13607860600641200 
Mackenzie, C.S., Pagura, J. \& Sareen, J. (2010). Correlates of perceived need for and use of mental health services by older adults in the collaborative psychiatric epidemiology surveys. The American Journal of Geriatric Psychiatry, 18(12), 1103-1115. doi: 10.1097/JGP.0b013e3181dd1c06

Mackenzie, C.S. Scott, T., Mather, A., \& Sareen, J. (2008). Older adults' help-seeking attitudes and treatment beliefs concerning mental health problems. The American Journal of Geriatric Psychiatry, 16(12), 1010-1019. doi: 10.1097/JGP.0b013e31818cd3be

Mccann, T.V., \& Bamberg, J. (2016). Carers of older adults' satisfaction with public mental health service clinicians: a qualitative study. Journal of Clinical Nursing, 25(11), 1634-1643. doi: $10.1111 /$ jocn. 13165

Mccormack, B., \& Skatvedt, A. (2017). Older people and their care partners' experiences of living with mental health needs: a focus on collaboration and cooperation. Journal of Clinical Nursing, 26(1), 103-114. doi: 10.1111/jocn.13381

Mcnulty, S.V., Duncan, L., Semple, M., \& Jackson, G. (2003). Care needs of elderly people with schizophrenia. Assessment of an epidemiologically defined cohort in Scotland. The British Journal of Psychiatry: The Journal Of Mental Science, 182, 241-247. doi: 10.1192/bjp.182.3.241

Moher, D., Liberati, A., Tetzlaff, J. et al. (2009). Preffered reporting items for systematic reviews and meta-analyses: the PRISMA statement. Annals of Internal Medicine. 151, 264-269.

Molyneux, C.J., McCarthty, G, M., McEniff., S., \& Cryan, M. (2008). Prevalence and predictors of carer burden and depression in carers of patients referred to an old age 30 psychiatric service. International Psychogeriatrics, 20(6), 1193-1202. doi: 10.1017/S1041610208007515

Morrow-Howell N.L., Proctor, E, K., Rubin, E, H., \& H. Li \& S Thompson. (2000) Service needs of depressed older adults following acute psychiatric care. Aging and Mental Health, 4(4), 330338. doi: 10.1080/713649968

Muir-Cochrane., E. O’Kane, D., Barkway, P., Oster C. \& Fuller, J. (2014). Service provision for older people with mental health problems in a rural area of Australia. Aging \& Mental Health, 18(6), 759-766. doi: 10.1080/13607863.2013.878307

National Heart, Lung and Blood Institute., (2018). Study Quality Assessment Tools. https://www.nhlbi.nih.gov/health-topics/study-quality-assessment-tools [Accessed 16/10/2018].

Nelson, C.H., \& Park, J. (2006). The nature and correlates of unmet health care needs in Ontario, Canada. Social science \& medicine, 62(9), 2291-2300. doi: 10.1016/j.socscimed.2005.10.014

Palinkas, L.A et al. (2007). Unmet needs for services for older adults with mental illness: Comparison of views of different stakeholder groups. The American Journal of Geriatric Psychiatry, 15(6), 530-540. doi: 10.1097/JGP.0b013e3180381505

Popay, J et al. (2006). Guidance on the conduct of Narrative Synthesis in Systematic Reviews: A Product from the ESRC Methods Programme. Lancaster.ac.uk.Retrieved 23 March 2018, from http://www.lancaster.ac.uk/shm/research/nssr/research/dissemination/publication/NS_Synthesis_ Guidance 31 
Preville, M., Boyer, M., \& Vasiliadis, H. (2010). Persistence and remission of psychiatric disorders in the Quebec older adult population. Canadian Journal of Psychiatry.Revue Canadienne De Psychiatrie, 55(8), 514-522

Robb, C., Haley., W.E., Becker., M.A., Polivka, L.A., \& Chaw, H.J. (2003). Attitudes towards mental health care in younger and older adults: Similarities and differences. Aging \& Mental Health, 7(2), 142-152 doi: 10.1080/1360786031000072321

Saad, K.,\& Bangash, A. (2016). Ageless mental health services and the future of old age psychiatry in the UK. Journal of Geriatric Care and Research. 3(1). 21-23.

Sarkin, A., Lale, R.., Sklar, M. et al. (2015). Stigma experienced by people using mental health services in San Diego County. Social Psychiatry and Psychiatry Epidemiology. 50 (5). 747-756. https://doi.org/10.1007/s00127-014-0979-9

Simning, A., Richardson, T. M., Friedman, B.,\& Boyle, L. L. (2010) Mental distress and service utilization among help-seeking, community-dwelling older adults. International Psychogeriatrics, 22(5), 739-749. doi: 10.1017/S104161021000058X

The Royal College of Psychiatrists (RCP), (2018). Suffering in silence: age inequality in older people's mental health care CR22. The Royal College of Psychiatrists.

Warner, J , \& Jenkison, J. (2013). Psychiatry for the elderly in the UK. The Lancet. 381., 19841985

Wells, J., Kennedy, C., Bain, H,. Lee, S.H. (2017). The experiences of older adults with a diagnosed functional mental illness, and their carers' / families' and healthcare professionals' experiences in relation to mental health service delivery. PROSPERO 2017 CRD42017080576. http://www.crd.york.ac.uk/PROSPERO/display_record.php?ID=CRD42017080576

Whittemore, R., \& Knafl, K. (2005). The integrative review: updated methodology: Methodological Issues in Nursing Research. Journal of Advanced Nursing. 52(5), 546-553.

World Data Bank. (2016). Population ages 65 and above (\% of total). Retrieved from https://data.worldbank.org/indicator/SP.POP.65UP.TO.ZS [Accessed 16/10/2018].

World Health Organisation (WHO). (2018). Mental Disorders. Retrieved from http://www.who.int/mediacentre/factsheets/fs396/en/ [Accessed 16/10/2018]. 


\section{Figure 1: PRISMA checklist}

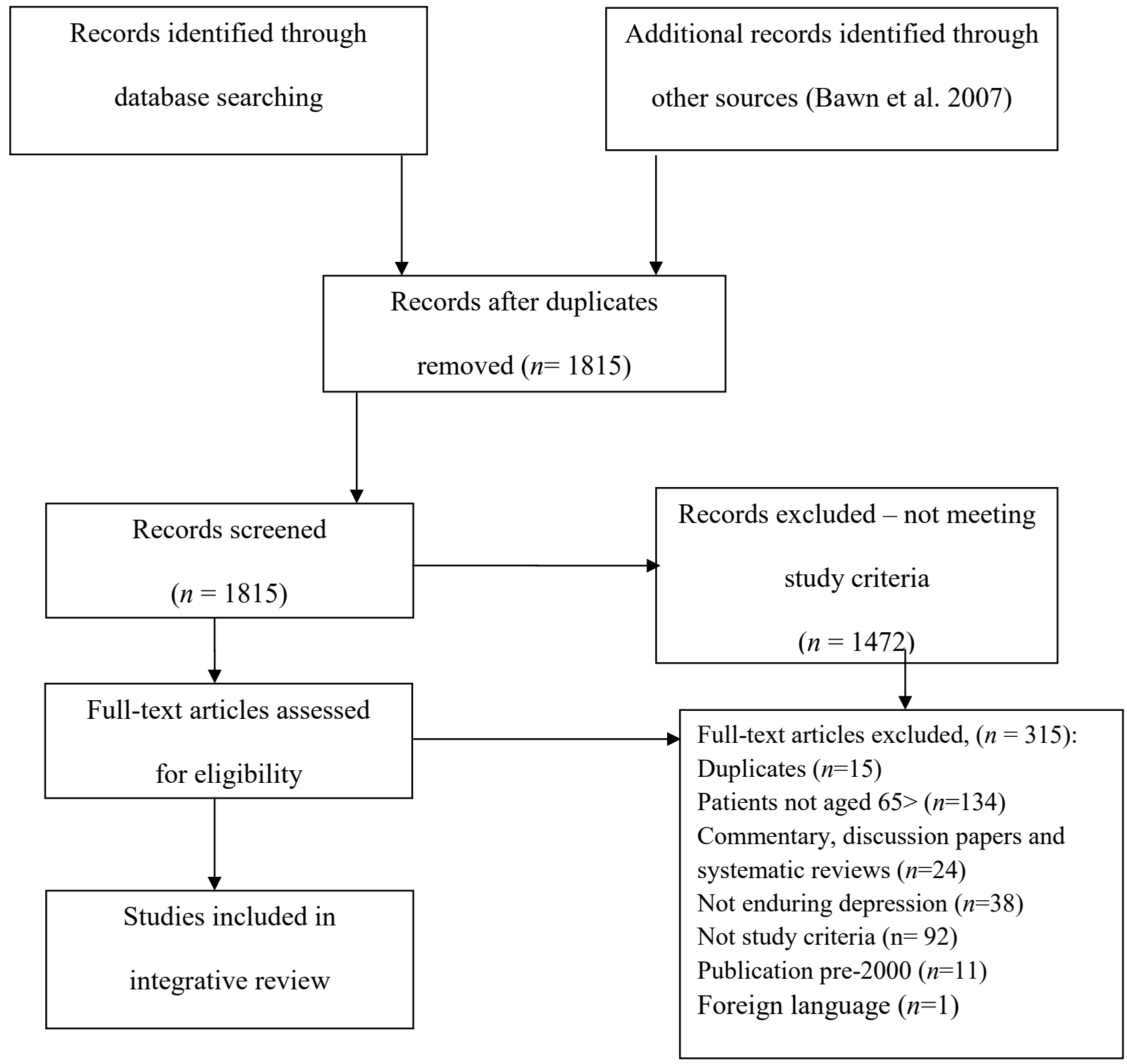




\section{Table 1: Inclusion and exclusion criteria}

\section{Types of study}

- Empirical research, including quantitative, qualitative, and mixed methods studies, was included in this review.

- Editorial, commentary, discussion, opinion papers, and systematic reviews were excluded.

- Papers on dementia, substance misuse, eating disorders, and alcohol use were excluded. Papers with a primary focus on physical health were also excluded.

\section{Types of population/participant}

- People aged over 65, with a diagnosed FMI were included in this review.

- Carers/families aged 18 and above. Carers or family members are defined in this review as a person who provides unpaid care to another person (Broady \& Stone 2015)

- Healthcare professionals (including nurses, support workers, social workers, medical staff, allied health professionals, and those working in third sector organisations) working in mental health service, for those aged over 65 who have a diagnosed FMI.

Table 2: MEDLINE Search

\begin{tabular}{|l|l|l|}
\hline \multicolumn{3}{|c|}{ MEDLINE Search: January 2000- October 2017 } \\
\hline Search & MeSH/Keywords & Hits \\
\hline 1. & (MH “Mental Disorders") & 14,129 \\
\hline
\end{tabular}




\begin{tabular}{|c|c|c|}
\hline 2. & (MH “Anxiety Disorders") & 29,918 \\
\hline 3. & (MH “Depressive Disorders”) & 67,442 \\
\hline 4. & "serious mental illness" & 2,831 \\
\hline 5. & "psychotic illness" & 1,274 \\
\hline 6. & (MH “Personality Disorders") & 19,145 \\
\hline 7. & (MH “Schizophrenia”) & 92,954 \\
\hline 8. & "functional mental illness" & 17 \\
\hline 9. & "mental illness" & 25,627 \\
\hline 10. & 1 or 2 or 3 or 4 or 5 or 6 or 7 or 8 or 9 & 340,263 \\
\hline 11. & (MH “Patients") & 19,099 \\
\hline 12. & "clients" & 31,478 \\
\hline 13. & "carers" & 10,048 \\
\hline 14. & "clients" & 31,478 \\
\hline 15. & "service users" & 3,578 \\
\hline 16. & "older adult mental health" & 40 \\
\hline 17. & "older people" & 17,202 \\
\hline 18. & "family carers" & 4,200 \\
\hline 19. & "families" & 211,899 \\
\hline 20. & "family caregivers" & 7,500 \\
\hline 21. & "family carers" & 66,700 \\
\hline 22. & "healthcare professionals" & 14,665 \\
\hline 23. & $\begin{array}{l}11 \text { or } 12 \text { or } 13 \text { or } 14 \text { or } 15 \text { or } 16 \text { or } 17 \text { or } 18 \text { or } \\
19 \text { or } 20 \text { or } 21 \text { or } 22\end{array}$ & 322,697 \\
\hline 24. & “old age psychiatry" & 1,252 \\
\hline
\end{tabular}




\begin{tabular}{|l|l|l|}
\hline 25. & "psychiatric services" & 3,857 \\
\hline 26. & (MH "Mental Health Services") & 29,798 \\
\hline 27. & "older adult mental health services" & 12 \\
\hline 28. & (MH "Community Mental Health Services") & 17,720 \\
\hline 29. & 24 or 25 or 26 or 27 or 28 & 50,554 \\
\hline 30. & 10 and 23 and 29 & 2,667 \\
\hline 31. & $\begin{array}{l}29 \text { and (limit year } 1^{\text {st }} \text { January 2000 - 30 } \\
\text { October 2017; English Language })\end{array}$ & 420 \\
\hline
\end{tabular}


Table 3: Evidence Summary of included studies

\begin{tabular}{|c|c|c|c|c|c|c|c|}
\hline $\begin{array}{l}\text { Author, year } \\
\& \text { Country }\end{array}$ & $\begin{array}{l}\text { Study design, data } \\
\text { collection and } \\
\text { method }\end{array}$ & Aim of the study & $\begin{array}{l}\text { Participant } \\
\text { characteristics / } \\
\text { sample size/ } \\
\text { setting }\end{array}$ & $\begin{array}{l}\text { Research Question } \\
\text { What are the experiences } \\
\text { of key stakeholders in } \\
\text { relation to mental health } \\
\text { services? }\end{array}$ & $\begin{array}{l}\text { Research Question } \\
\text { What are key stakeholders' } \\
\text { experiences in relation to } \\
\text { accessibility and availability } \\
\text { of mental health services? }\end{array}$ & Key findings & $\begin{array}{l}\text { Quality } \\
\text { Appraisal }\end{array}$ \\
\hline $\begin{array}{l}\text { Abdul-Hamid } \\
\text { et al. (2016) } \\
\text { UK }\end{array}$ & $\begin{array}{l}\text { Quantitative } \\
\text { (Cross- sectional } \\
\text { survey) } \\
\text { Assessment using } \\
\text { Elderly } \\
\text { Psychiatric Needs } \\
\text { Schedule (EPNS) }\end{array}$ & $\begin{array}{l}\text { To compare OAMH services with } \\
\text { general psychiatric wards in relation } \\
\text { to unmet need in over } 65 \text { year olds. }\end{array}$ & $\begin{array}{l}\text { Elderly patients } \\
\text { with functional } \\
\text { psychiatric } \\
\text { disorders }(n=74) \\
\text { Community } \\
\text { Setting }\end{array}$ & $\begin{array}{l}\text { Authors found unmet need } \\
\text { higher in those patients in } \\
\text { ageless services across all } \\
\text { domains of the EPNS. }\end{array}$ & Not discussed & $\begin{array}{l}\text { Authors consider their } \\
\text { findings to support models } \\
\text { of ageless services. }\end{array}$ & $\begin{array}{l}\text { NIHBL } \\
\text { Yes to all } \\
\text { questions }\end{array}$ \\
\hline $\begin{array}{l}\text { Anderson and } \\
\text { Lewis (2000) } \\
\text { USA }\end{array}$ & $\begin{array}{l}\text { Quantitative } \\
\text { Completion of } \\
\text { Quality of Life } \\
\text { (QoL) } \\
\text { psychometric } \\
\text { properties }\end{array}$ & $\begin{array}{l}\text { To examine the QoL in association } \\
\text { with resident's characteristics who } \\
\text { lived in an Intermediate Care } \\
\text { Facility }\end{array}$ & $\begin{array}{l}\text { People aged } \\
\text { over } 60 \text { with } \\
\text { Schizophrenia or } \\
\text { Affective } \\
\text { disorder }(n=100) \\
\text { Intermediate } \\
\text { Care Facility }\end{array}$ & $\begin{array}{l}\text { Poorer contact with family } \\
\text { members and lower QoL } \\
\text { than those living in a state } \\
\text { hospital. } \\
\text { Patients dissatisfied with } \\
\text { their finances. }\end{array}$ & Not discussed & $\begin{array}{l}\text { People within an } \\
\text { Intermediate Care facility } \\
\text { had lower Qol in all domains } \\
\text { than those living in state } \\
\text { hospital. } \\
\text { Patients had financial } \\
\text { dissatisfaction. }\end{array}$ & $\begin{array}{l}\text { CASP } \\
10\end{array}$ \\
\hline $\begin{array}{l}\text { Arean et al. } \\
(2007) \\
\text { USA }\end{array}$ & $\begin{array}{l}\text { Quantitative } \\
\text { Randomised } \\
\text { Control Trial }\end{array}$ & $\begin{array}{l}\text { To explore the use of mental health } \\
\text { care by low income older adults. }\end{array}$ & $\begin{array}{l}\text { Patients aged } 60 \\
\text { and over with a } \\
\text { diagnosis of } \\
\text { depression } \\
(n=1801) \\
\text { Muti-sites } \\
\text { Primary care }\end{array}$ & $\begin{array}{l}\text { An integrated model in } \\
\text { primary care, including } \\
\text { mental health practitioners } \\
\text { improved the outcome for } \\
\text { lower income people with } \\
\text { depression.. This was } \\
\text { because of a lack of routine } \\
\text { screening for depression in } \\
\text { primary care. }\end{array}$ & Not discussed & $\begin{array}{l}\text { Integration of depression } \\
\text { treatment into primary care } \\
\text { improves use of service by } \\
\text { low income elders. } \\
\text { Mental health practitioners } \\
\text { screen for depression in a } \\
\text { primary care service which } \\
\text { would ordinarily be missed. } \\
\text { Limitation } \\
\text { Participants were not } \\
\text { stratified and were }\end{array}$ & $\begin{array}{l}\text { CASP } \\
9 / 10\end{array}$ \\
\hline
\end{tabular}




\begin{tabular}{|c|c|c|c|c|c|c|c|}
\hline $\begin{array}{l}\text { Author, year } \\
\text { \& Country }\end{array}$ & $\begin{array}{l}\text { Study design, data } \\
\text { collection and } \\
\text { method }\end{array}$ & Aim of the study & $\begin{array}{l}\text { Participant } \\
\text { characteristics / } \\
\text { sample size/ } \\
\text { setting }\end{array}$ & $\begin{array}{l}\text { Research Question } \\
\text { What are the experiences } \\
\text { of key stakeholders in } \\
\text { relation to mental health } \\
\text { services? }\end{array}$ & $\begin{array}{l}\text { Research Question } \\
\text { What are key stakeholders' } \\
\text { experiences in relation to } \\
\text { accessibility and availability } \\
\text { of mental health services? }\end{array}$ & Key findings & $\begin{array}{l}\text { Quality } \\
\text { Appraisal }\end{array}$ \\
\hline & & & & & & $\begin{array}{l}\text { volunteers perhaps with } \\
\text { some biased opinion. }\end{array}$ & \\
\hline $\begin{array}{l}\text { Bawn et al. } \\
\text { (2007) } \\
\text { UK }\end{array}$ & $\begin{array}{l}\text { Quantitative } \\
\text { Survey }\end{array}$ & $\begin{array}{l}\text { To investigate how CR110 (Royal } \\
\text { College of Psychiatry Report) has } \\
\text { influenced policies relating to the } \\
\text { transfer of people with long } \\
\text { standing mental illness to older } \\
\text { adult services. }\end{array}$ & \begin{tabular}{|l}
$\begin{array}{l}\text { Healthcare } \\
\text { professionals } \\
(n=55)\end{array}$ \\
Community \\
Setting
\end{tabular} & $\begin{array}{l}\text { Adult services are better } \\
\text { funded and have more } \\
\text { MDT input. Services } \\
\text { should be needs led and not } \\
\text { age led. A noted lack of } \\
\text { joint up working. }\end{array}$ & Not discussed & $\begin{array}{l}\text { Protocols regarding age } \\
\text { transition were found to be } \\
\text { beneficial. Services should } \\
\text { be needs led not age led. } \\
\text { Limitations } \\
\text { Patients/carers not asked } \\
\text { about their experiences. } \\
\text { Mangers consulted who with } \\
\text { minimal patient contact. }\end{array}$ & $\begin{array}{l}\text { CASP } \\
6 / 10\end{array}$ \\
\hline $\begin{array}{l}\text { Broady and } \\
\text { Stone (2015) } \\
\text { New Zealand }\end{array}$ & $\begin{array}{l}\text { Quantitative } \\
\text { Survey }\end{array}$ & $\begin{array}{l}\text { To investigate carers experience of } \\
\text { health and well being of those who } \\
\text { care for someone with a mental } \\
\text { illness compared to those who care } \\
\text { for someone who does not. }\end{array}$ & \begin{tabular}{|l} 
Carers $(n=1916)$ \\
Community \\
setting
\end{tabular} & $\begin{array}{l}\text { Mental health carers paid } \\
\text { less attention to their own } \\
\text { health compared to other } \\
\text { carers. } \\
\text { Being a carer for someone } \\
\text { with mental health likely to } \\
\text { affect individuals own } \\
\text { health and emotional } \\
\text { burden. }\end{array}$ & $\begin{array}{l}\text { One in four carers were } \\
\text { unable to access the support } \\
\text { they needed, due to time } \\
\text { constraints of caring role and } \\
\text { cost implications. } \\
\text { Carers were likely to } \\
\text { experience barriers accessing } \\
\text { services. }\end{array}$ & $\begin{array}{l}\text { Carers of people with mental } \\
\text { health more likely to need } \\
\text { support but less likely to } \\
\text { access due to time and } \\
\text { financial constraints. } \\
\text { Carers experienced poor } \\
\text { physical and mental health } \\
\text { themselves. } \\
\text { Limitations } \\
\text { Findings may be skewed by } \\
\text { carers who are more willing } \\
\text { to participate and may not be } \\
\text { representative of general } \\
\text { population. } \\
\text { Age group of patients not } \\
\text { provided. }\end{array}$ & $\begin{array}{l}\text { CASP } \\
10 / 10\end{array}$ \\
\hline
\end{tabular}




\begin{tabular}{|c|c|c|c|c|c|c|c|}
\hline $\begin{array}{l}\text { Author, year } \\
\text { \& Country }\end{array}$ & $\begin{array}{l}\text { Study design, data } \\
\text { collection and } \\
\text { method }\end{array}$ & Aim of the study & \begin{tabular}{|l|} 
Participant \\
characteristics / \\
sample size/ \\
setting
\end{tabular} & $\begin{array}{l}\text { Research Question } \\
\text { What are the experiences } \\
\text { of key stakeholders in } \\
\text { relation to mental health } \\
\text { services? }\end{array}$ & $\begin{array}{l}\text { Research Question } \\
\text { What are key stakeholders' } \\
\text { experiences in relation to } \\
\text { accessibility and availability } \\
\text { of mental health services? }\end{array}$ & Key findings & $\begin{array}{l}\text { Quality } \\
\text { Appraisal }\end{array}$ \\
\hline $\begin{array}{l}\text { Byers et al. } \\
\text { (2008) } \\
\text { UK }\end{array}$ & $\begin{array}{l}\text { Quantitative } \\
\text { Survey }\end{array}$ & $\begin{array}{l}\text { Survey of prevalence and key } \\
\text { factors of non use of mental health } \\
\text { services in older adults. }\end{array}$ & $\begin{array}{l}\text { Adults aged 55 } \\
\text { and over with a } \\
\text { mood disorder } \\
(n=348) \\
\text { Community } \\
\text { setting }\end{array}$ & $\begin{array}{l}\text { Many patients had chronic } \\
\text { pain but perceived low } \\
\text { need around mental health, } \\
\text { leading to the belief that } \\
\text { pain was psychosomatic. }\end{array}$ & $\begin{array}{l}\text { Vast majority of respondents } \\
\text { with low mood or anxiety } \\
\text { did not access services due to } \\
\text { low perceived need, lack of } \\
\text { motivation and moderate } \\
\text { resources. People of ethnic } \\
\text { origin were more likely not } \\
\text { to seek support. }\end{array}$ & $\begin{array}{l}\text { Older people embarrassed to } \\
\text { seek support for mental } \\
\text { health. Perceived low need } \\
\text { affected decision Making to } \\
\text { seek support and people of } \\
\text { ethnic origin less likely to } \\
\text { seek support. } \\
\text { Limitations } \\
\text { Depressive symptoms may } \\
\text { be secondary and therefore } \\
\text { not a true representation }\end{array}$ & $\begin{array}{l}\text { CASP } \\
9 / 10\end{array}$ \\
\hline $\begin{array}{l}\text { Clancy and } \\
\text { Baldwin } \\
\text { (2008) UK }\end{array}$ & $\begin{array}{l}\text { Quantitative } \\
\text { Comparative } \\
\text { study }\end{array}$ & $\begin{array}{l}\text { Comparative study of older people } \\
\text { living in their own home and care } \\
\text { homes. }\end{array}$ & $\begin{array}{l}\text { Older adults } \\
\text { with } \\
\text { Schizophrenia } \\
(n=23) \\
\text { Community }\end{array}$ & $\begin{array}{l}\text { Individuals living in care } \\
\text { homes have higher levels } \\
\text { of symptomology such as } \\
\text { medical co-morbidity and } \\
\text { negative symptoms of } \\
\text { Schizophrenia and are far } \\
\text { less likely to be } \\
\text { independent with activities } \\
\text { of daily living. }\end{array}$ & Not discussed. & $\begin{array}{l}\text { Those living in care homes } \\
\text { had more positive and } \\
\text { negative symptoms o } \\
\text { Schizophrenia. } \\
\text { Those living in care homes } \\
\text { were less independent with } \\
\text { activities of daily living. }\end{array}$ & $\begin{array}{l}\text { CASP } \\
8 / 10\end{array}$ \\
\hline $\begin{array}{l}\text { Crabb and } \\
\text { Hunsley } \\
(2006) \\
\text { USA }\end{array}$ & $\begin{array}{l}\text { Quantitative } \\
\text { Survey }\end{array}$ & $\begin{array}{l}\text { Comparison of mental health service } \\
\text { use by middle aged adults and older } \\
\text { adults. }\end{array}$ & $\begin{array}{l}\text { People aged 45- } \\
64(n=35,958) \\
\text { Aged } 65-74 \\
(n=12,788) \\
75 \text { years and } \\
\text { older }(n=10,576) \\
\text { Community } \\
\text { setting }\end{array}$ & $\begin{array}{l}\text { Perceived self resilience, } \\
\text { inner strength and } \\
\text { resilience. }\end{array}$ & \begin{tabular}{|l|} 
Older people with physical \\
co-morbidity were more \\
likely to seek help from \\
mental health services \\
The older the person, the less \\
likely they are to seek mental \\
health support from \\
specialist services.
\end{tabular} & $\begin{array}{l}\text { Adults aged } 65 \text { and over are } \\
\text { less likely to seek support } \\
\text { for depression than those } \\
\text { aged } 45-64 \\
\text { In all age groups people } \\
\text { more likely to approach a } \\
\text { physician about depression } \\
\text { than a psychiatrist. } \\
\text { Limitations }\end{array}$ & $\begin{array}{l}\text { CASP } \\
8 / 10\end{array}$ \\
\hline
\end{tabular}




\begin{tabular}{|c|c|c|c|c|c|c|c|}
\hline $\begin{array}{l}\text { Author, year } \\
\& \text { Country }\end{array}$ & $\begin{array}{l}\text { Study design, data } \\
\text { collection and } \\
\text { method }\end{array}$ & Aim of the study & $\begin{array}{l}\text { Participant } \\
\text { characteristics / } \\
\text { sample size/ } \\
\text { setting }\end{array}$ & $\begin{array}{l}\text { Research Question } \\
\text { What are the experiences } \\
\text { of key stakeholders in } \\
\text { relation to mental health } \\
\text { services? }\end{array}$ & $\begin{array}{l}\text { Research Question } \\
\text { What are key stakeholders' } \\
\text { experiences in relation to } \\
\text { accessibility and availability } \\
\text { of mental health services? }\end{array}$ & Key findings & $\begin{array}{l}\text { Quality } \\
\text { Appraisal }\end{array}$ \\
\hline & & & & & & $\begin{array}{l}\text { Wide sample group of where } \\
\text { people live. }\end{array}$ & \\
\hline $\begin{array}{l}\text { Cummings } \\
(2009) \\
\text { USA }\end{array}$ & $\begin{array}{l}\text { Quantitative } \\
\text { Descriptive and } \\
\text { experimental } \\
\text { design } \\
\text { Assessments on } \\
\text { depression and } \\
\text { life satisfaction. }\end{array}$ & $\begin{array}{l}\text { To explore the need and unmet need } \\
\text { in older adults with severe mental } \\
\text { illness }\end{array}$ & $\begin{array}{l}\text { People with } \\
\text { severe mental } \\
\text { illness aged } 65 \\
\text { and over }(n=75) \\
\text { Community } \\
\text { setting }\end{array}$ & $\begin{array}{l}70 \% \text { of participants did not } \\
\text { receive the support they } \\
\text { needed. } \\
\text { Those with physical needs } \\
\text { relied heavily on families } \\
\text { to support them } \\
\text { People received more } \\
\text { support for their mental } \\
\text { health than physical needs. }\end{array}$ & Not discussed & $\begin{array}{l}\text { Patients were far less likely } \\
\text { to experience assistance with } \\
\text { both physical and mental } \\
\text { health needs. } \\
\text { Limited assistance with } \\
\text { financial matters. } \\
\text { Limitations } \\
\text { The findings cant be } \\
\text { generalised as the study } \\
\text { focused on CMHT only }\end{array}$ & $\begin{array}{l}\text { CASP } \\
8 / 10\end{array}$ \\
\hline $\begin{array}{l}\text { Fulford and } \\
\text { Farhall (2001) } \\
\text { Australia }\end{array}$ & $\begin{array}{l}\text { Quantitative } \\
\text { Questionnaire }\end{array}$ & $\begin{array}{l}\text { To explore the experiences of carers } \\
\text { in relation to care during acute } \\
\text { psychosis. }\end{array}$ & $\begin{array}{l}\text { Carer of a } \\
\text { person with SMI } \\
(n=77) \\
\text { Community and } \\
\text { hospital setting }\end{array}$ & $\begin{array}{l}\text { The majority of } \\
\text { participants preferred } \\
\text { hospital care compared to } \\
\text { assertive outreach. } \\
\text { Carers felt less burden } \\
\text { from managing the illness } \\
\text { and felt there was less } \\
\text { chance of relapse. }\end{array}$ & Not discussed & $\begin{array}{l}\text { Proportion of care givers } \\
\text { who prefer assertive } \\
\text { outreach to hospital } \\
\text { admission is less than } \\
\text { thought. } \\
\text { Limitations } \\
\text { Low response rate and } \\
\text { patient views not explored. }\end{array}$ & $\begin{array}{l}\text { CASP } \\
7 / 10\end{array}$ \\
\hline $\begin{array}{l}\text { Holvast et al. } \\
(2012) \\
\text { Holland }\end{array}$ & $\begin{array}{l}\text { Quantitative } \\
\text { cohort study }\end{array}$ & $\begin{array}{l}\text { The study identifies and analyses } \\
\text { factors that determine whether } \\
\text { elderly people with depression } \\
\text { receive treatment or not. }\end{array}$ & $\begin{array}{l}\text { Older people } \\
\text { aged } 65 \text { and over } \\
(n=167) \\
\text { Primary care }\end{array}$ & Not discussed & $\begin{array}{l}70 \% \text { of people with } \\
\text { depression saw their } \\
\text { physician almost exclusively } \\
\text { compared to specialist } \\
\text { services. } \\
\text { Most people sought help for } \\
\text { their mental health from their } \\
\text { physician }\end{array}$ & $\begin{array}{l}\text { Elderly people and their } \\
\text { physicians think depression } \\
\text { is a normal part of aging. } \\
\text { Limitations } \\
\text { Urbanised areas over } \\
\text { represented. }\end{array}$ & $\begin{array}{l}\text { CASP } \\
10 / 10\end{array}$ \\
\hline
\end{tabular}




\begin{tabular}{|c|c|c|c|c|c|c|c|}
\hline $\begin{array}{l}\text { Author, year } \\
\text { \& Country }\end{array}$ & $\begin{array}{l}\text { Study design, data } \\
\text { collection and } \\
\text { method }\end{array}$ & Aim of the study & $\begin{array}{l}\text { Participant } \\
\text { characteristics / } \\
\text { sample size/ } \\
\text { setting }\end{array}$ & $\begin{array}{l}\text { Research Question } \\
\text { What are the experiences } \\
\text { of key stakeholders in } \\
\text { relation to mental health } \\
\text { services? }\end{array}$ & $\begin{array}{l}\text { Research Question } \\
\text { What are key stakeholders' } \\
\text { experiences in relation to } \\
\text { accessibility and availability } \\
\text { of mental health services? }\end{array}$ & Key findings & $\begin{array}{l}\text { Quality } \\
\text { Appraisal }\end{array}$ \\
\hline $\begin{array}{l}\text { Houtjes et al. } \\
\text { (2011) } \\
\text { Holland }\end{array}$ & $\begin{array}{l}\text { Quantitative } \\
\text { Cross sectional } \\
\text { survey }\end{array}$ & $\begin{array}{l}\text { To gain insight into the unmet needs } \\
\text { of outpatients with late life } \\
\text { depression. }\end{array}$ & $\begin{array}{l}\text { Patients }(n=99) \\
\text { Carers }(n=96) \\
\text { Healthcare } \\
\text { professionals } \\
(n=85)\end{array}$ & $\begin{array}{l}\text { Patients had a higher } \\
\text { perception of unmet need } \\
\text { that their healthcare } \\
\text { professionals did. } \\
\text { Carers and patients had } \\
\text { different perceptions on } \\
\text { unmet need. } \\
\text { Patient staff contact was } \\
\text { felt to be insufficient }\end{array}$ & Not discussed & $\begin{array}{l}\text { Patient's depression severity } \\
\text { correlated with their unmet } \\
\text { need. } \\
\text { Patients, carers and } \\
\text { healthcare professionals all } \\
\text { had different perceptions } \\
\text { around un met need. } \\
\text { Limitations } \\
\text { Patients with severe } \\
\text { depressive disorder under } \\
\text { represented. }\end{array}$ & $\begin{array}{l}\text { NIHLB } \\
\text { Yes all } \\
\text { questions }\end{array}$ \\
\hline $\begin{array}{l}\text { Karlin and } \\
\text { Norris (2006) } \\
\text { USA }\end{array}$ & $\begin{array}{l}\text { Quantitative } \\
\text { Data collected } \\
\text { from CARE } \\
\text { system }\end{array}$ & $\begin{array}{l}\text { To investigate the extent to which } \\
\text { older }(60+) \text { versus younger }(18-59) \\
\text { adults begin treatment in the public } \\
\text { mental health sector in relation to } \\
\text { psychotherapy. }\end{array}$ & $\begin{array}{l}\text { People aged } 18 \\
\text { and over } \\
(n=12,810) \\
\text { Community } \\
\text { setting }\end{array}$ & $\begin{array}{l}\text { Urban consumers less } \\
\text { distressed than those in } \\
\text { rural areas. }\end{array}$ & $\begin{array}{l}\text { Older adults were more } \\
\text { likely to access services } \\
\text { when they were cost free. }\end{array}$ & $\begin{array}{l}\text { Only } 5 \% \text { of the population } \\
\text { using mental health services } \\
\text { were aged over } 65 . \\
\text { Older adults more likely to } \\
\text { use services when they are } \\
\text { free. } \\
\text { Limitations } \\
\text { Data was collected } \\
\text { retrospectively } \\
\text { Ethnic groups over } \\
\text { represented. }\end{array}$ & $\begin{array}{l}\text { CASP } \\
8 / 10\end{array}$ \\
\hline $\begin{array}{l}\text { Mackenzie et } \\
\text { al. (2006) } \\
\text { Canada }\end{array}$ & $\begin{array}{l}\text { Quantitative } \\
\text { Questionnaire }\end{array}$ & $\begin{array}{l}\text { To explore age and gender attitudes } \\
\text { towards seeking professional and } \\
\text { psychological help and to examine } \\
\text { whether attitudes negatively } \\
\text { influence intentions to seek help } \\
\text { among older adults. }\end{array}$ & \begin{tabular}{|l|} 
Men $(n=105)$ \\
Women $(n=95)$ \\
Community
\end{tabular} & Not discussed & $\begin{array}{l}\text { People preferred to speak to } \\
\text { a friend and then their } \\
\text { physician rather than } \\
\text { specialist services. } \\
\text { Older people found it easier } \\
\text { to speak to their physician } \\
\text { about their mental health } \\
\text { compared to younger people. }\end{array}$ & $\begin{array}{l}\text { Men viewed mental health } \\
\text { as weakness which affected } \\
\text { their decisions to seek } \\
\text { support. } \\
\text { Older peoples find it easier } \\
\text { to access mental health } \\
\text { services than perhaps other } \\
\text { studies suggest. }\end{array}$ & $\begin{array}{l}\text { CASP } \\
8 / 10\end{array}$ \\
\hline
\end{tabular}




\begin{tabular}{|c|c|c|c|c|c|c|c|}
\hline $\begin{array}{l}\text { Author, year } \\
\text { \& Country }\end{array}$ & $\begin{array}{l}\text { Study design, data } \\
\text { collection and } \\
\text { method }\end{array}$ & Aim of the study & $\begin{array}{l}\text { Participant } \\
\text { characteristics / } \\
\text { sample size/ } \\
\text { setting }\end{array}$ & $\begin{array}{l}\text { Research Question } \\
\text { What are the experiences } \\
\text { of key stakeholders in } \\
\text { relation to mental health } \\
\text { services? }\end{array}$ & $\begin{array}{l}\text { Research Question } \\
\text { What are key stakeholders' } \\
\text { experiences in relation to } \\
\text { accessibility and availability } \\
\text { of mental health services? }\end{array}$ & Key findings & $\begin{array}{l}\text { Quality } \\
\text { Appraisal }\end{array}$ \\
\hline & & & & & & $\begin{array}{l}\text { Limitations } \\
\text { Data collection took place at } \\
\text { a train station, perhaps } \\
\text { missing the population of } \\
\text { people with mental illness. }\end{array}$ & \\
\hline $\begin{array}{l}\text { Mackenzie et } \\
\text { al. (2010) } \\
\text { USA }\end{array}$ & $\begin{array}{l}\text { Quantitative } \\
\text { Survey }\end{array}$ & $\begin{array}{l}\text { To examine sociodemographic and } \\
\text { mental health correlates of whether } \\
\text { older adults sought professionals } \\
\text { help, perceived the need for help } \\
\text { without seeking it and sought help } \\
\text { from mental health professionals. }\end{array}$ & $\begin{array}{l}\text { People aged } 55 \\
\text { and over } \\
(n=3017) \\
\text { Community }\end{array}$ & Not discussed & $\begin{array}{l}\text { Perception of need was a } \\
\text { significant barrier in } \\
\text { accessing mental health } \\
\text { services. Majority of people } \\
\text { want to sort the problem } \\
\text { them self and only } 16 \% \text { of } \\
\text { older people sought } \\
\text { specialist help, preferring to } \\
\text { see their physician. }\end{array}$ & $\begin{array}{l}\text { Older people did not } \\
\text { perceive they had a mental } \\
\text { health need and wanted to be } \\
\text { self sufficient. } \\
\text { Limitations } \\
\text { Questionnaire does not } \\
\text { include help seeking } \\
\text { perceptions, therefore } \\
\text { findings cannot be } \\
\text { generalised. }\end{array}$ & $\begin{array}{l}\text { CASP } \\
8 / 10\end{array}$ \\
\hline $\begin{array}{l}\text { Mackenzie et } \\
\text { al. (2008) } \\
\text { USA }\end{array}$ & $\begin{array}{l}\text { Quantitative } \\
\text { National co- } \\
\text { morbidity survey }\end{array}$ & $\begin{array}{l}\text { To compare older adults' attitudes } \\
\text { and beliefs to younger adults' and to } \\
\text { examine the influence of age on } \\
\text { these variables after controlling for } \\
\text { other demographic variables, prior } \\
\text { help-seeking, and mental disorders. }\end{array}$ & $\begin{array}{l}\begin{array}{l}\text { Community } \\
\text { dwelling people } \\
(n=5692\end{array} \\
\text { Adults aged } 65 \\
\text { and over } \\
(n=1341) \\
\text { Community }\end{array}$ & $\begin{array}{l}\text { Age was a significant } \\
\text { factor in people's } \\
\text { willingness to seek } \\
\text { professional help as it was } \\
\text { in relation to concern if a } \\
\text { friend found out that they } \\
\text { needed help. } \\
\text { Younger adults also had } \\
\text { more positive beliefs about } \\
\text { the effectiveness of mental } \\
\text { health services. } \\
\text { There was no difference in } \\
\text { younger people compared } \\
\text { to older people in terms of }\end{array}$ & $\begin{array}{l}80 \% \text { had a positive help- } \\
\text { seeking experience in terms } \\
\text { of attitudes. } \\
\text { However, the person's age } \\
\text { had a significant bearing on } \\
\text { professional help seeking } \\
\text { with those over } 65 \text { less likely } \\
\text { to seek help. }\end{array}$ & $\begin{array}{l}\text { Older Americans do not } \\
\text { have negative help-seeking } \\
\text { attitudes or negative beliefs } \\
\text { about the efficacy of } \\
\text { treatment for mental health } \\
\text { problems. } 80 \% \text { of adults } \\
\text { aged } 55 \text { and older had } \\
\text { positive attitudes, and more } \\
\text { than } 70 \% \text { had positive } \\
\text { treatment beliefs. Results } \\
\text { also show that older adults' } \\
\text { attitudes are positive relative } \\
\text { to younger adults'. } \\
\text { Limitations }\end{array}$ & $\begin{array}{l}\text { CASP } \\
8 / 10\end{array}$ \\
\hline
\end{tabular}




\begin{tabular}{|c|c|c|c|c|c|c|c|}
\hline $\begin{array}{l}\text { Author, year } \\
\& \text { Country }\end{array}$ & $\begin{array}{l}\text { Study design, data } \\
\text { collection and } \\
\text { method }\end{array}$ & Aim of the study & \begin{tabular}{|l|} 
Participant \\
characteristics / \\
sample size/ \\
setting
\end{tabular} & $\begin{array}{l}\text { Research Question } \\
\text { What are the experiences } \\
\text { of key stakeholders in } \\
\text { relation to mental health } \\
\text { services? }\end{array}$ & $\begin{array}{l}\text { Research Question } \\
\text { What are key stakeholders' } \\
\text { experiences in relation to } \\
\text { accessibility and availability } \\
\text { of mental health services? }\end{array}$ & Key findings & $\begin{array}{l}\text { Quality } \\
\text { Appraisal }\end{array}$ \\
\hline & & & & $\begin{array}{l}\text { beliefs about treatment } \\
\text { effectiveness. }\end{array}$ & & $\begin{array}{l}\text { The study only focussed on } \\
\text { community living people, } \\
\text { and therefore those in } \\
\text { hospital's views were not } \\
\text { sought }\end{array}$ & \\
\hline $\begin{array}{l}\text { McCann et al. } \\
\text { (2016) } \\
\text { Australia }\end{array}$ & $\begin{array}{l}\text { Qualitative } \\
\text { Semi structured } \\
\text { interviews }\end{array}$ & $\begin{array}{l}\text { To explore caregivers' } \\
\text { experience of the way public mental } \\
\text { health nurses and other mental } \\
\text { health clinicians responded to them } \\
\text { as carers of older adults with mental } \\
\text { illness. }\end{array}$ & $\begin{array}{l}\text { Carers of people } \\
\text { with } \\
\text { mental } \\
\text { illness aged } 65 \\
\text { and over }(n=30) \\
\\
\text { Community }\end{array}$ & $\begin{array}{l}\text { Generally clinicians were } \\
\text { viewed as supportive. } \\
\text { However, carers felt their } \\
\text { contribution was } \\
\text { undervalued by clinicians } \\
\text { and they felt left out of } \\
\text { decision making. } \\
\text { Failure to provide } \\
\text { culturally appropriate } \\
\text { meals }\end{array}$ & $\begin{array}{l}\text { Carers expressed not getting } \\
\text { enough help, lack of } \\
\text { information }\end{array}$ & $\begin{array}{l}\text { Carers felt uninvolved in } \\
\text { decision making about their } \\
\text { relatives care. They } \\
\text { generally felt undervalued, } \\
\text { not involved and that poor } \\
\text { care was delivered. } \\
\text { Limitations: Recruitment } \\
\text { from carers who are well } \\
\text { engaged with a service may } \\
\text { not reflect the views of } \\
\text { people not so well engaged. }\end{array}$ & $\begin{array}{l}\text { CASP } \\
9 / 10\end{array}$ \\
\hline $\begin{array}{l}\text { McCormack } \\
\text { and Skatvedt } \\
\text { (2017) } \\
\text { Norway }\end{array}$ & $\begin{array}{l}\text { Qualitative } \\
\text { Action research }\end{array}$ & $\begin{array}{l}\text { To explore how older people living } \\
\text { at home with mental health needs } \\
\text { and their care partners experienced } \\
\text { the practices of collaboration within } \\
\text { and between services. }\end{array}$ & 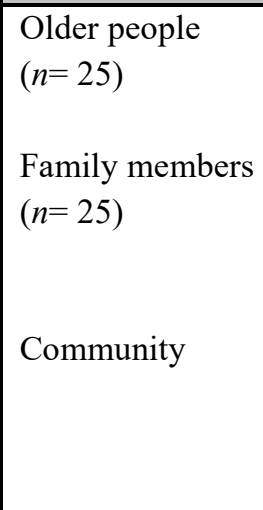 & $\begin{array}{l}\text { Patients felt they weren't } \\
\text { seen as a person by } \\
\text { healthcare professionals } \\
\text { did not care about the } \\
\text { person. Carers felt tired } \\
\text { with the system and } \\
\text { inability to provide the } \\
\text { correct care. } \\
\text { Person centred } \\
\text { collaborative care was not } \\
\text { experienced. }\end{array}$ & $\begin{array}{l}\text { Help not offered early } \\
\text { enough or in collaboration } \\
\text { with other services, from the } \\
\text { carers perspective. } \\
\text { Ageist attitudes more help } \\
\text { available when the person } \\
\text { was younger. From the carers } \\
\text { perspective }\end{array}$ & $\begin{array}{l}\text { Nurses and care workers } \\
\text { need to pay attention to the } \\
\text { emotional engagement with } \\
\text { older people that is needed } \\
\text { to help them cope with their } \\
\text { day-to-day life situation. } \\
\text { Limitations: } \\
\text { Small sample size in a } \\
\text { specific location }\end{array}$ & $\begin{array}{l}\text { CASP } \\
10 / 10\end{array}$ \\
\hline
\end{tabular}




\begin{tabular}{|c|c|c|c|c|c|c|c|}
\hline $\begin{array}{l}\text { Author, year } \\
\& \text { Country }\end{array}$ & $\begin{array}{l}\text { Study design, data } \\
\text { collection and } \\
\text { method }\end{array}$ & Aim of the study & \begin{tabular}{|l|} 
Participant \\
characteristics / \\
sample size/ \\
setting
\end{tabular} & $\begin{array}{l}\text { Research Question } \\
\text { What are the experiences } \\
\text { of key stakeholders in } \\
\text { relation to mental health } \\
\text { services? }\end{array}$ & $\begin{array}{l}\text { Research Question } \\
\text { What are key stakeholders' } \\
\text { experiences in relation to } \\
\text { accessibility and availability } \\
\text { of mental health services? }\end{array}$ & Key findings & $\begin{array}{l}\text { Quality } \\
\text { Appraisal }\end{array}$ \\
\hline & & & & $\begin{array}{l}\text { A belief that nurses and } \\
\text { carers didn't care about } \\
\text { patient. Carers perspective }\end{array}$ & & & \\
\hline $\begin{array}{l}\text { McNulty et al. } \\
(2003) \\
\text { UK }\end{array}$ & $\begin{array}{l}\text { Quantitative } \\
\text { Interview using } \\
\text { Cardinal Needs } \\
\text { Schedule }\end{array}$ & $\begin{array}{l}\text { To measure the } \\
\text { care needs of an Epidemiologically } \\
\text { based group of patients over the age } \\
\text { of } 65 \text { years suffering from Psychotic } \\
\text { illness, using a standardised } \\
\text { assessment }\end{array}$ & $\begin{array}{l}\text { Adults aged } 65 \\
\text { and over with a } \\
\text { diagnosis of } \\
\text { Functional } \\
\text { mental health } \\
\text { illness }(n=58) \\
\\
\text { Community }\end{array}$ & $\begin{array}{l}\text { Participants had on average } \\
0.9 \text { clinical needs and } 1.7 \\
\text { social needs. Using the } \\
\text { persistent problem despite } \\
\text { intervention scale. } \\
\text { Lanarkshire has the second } \\
\text { highest level of need in } \\
\text { Scotland but lowest budget. } \\
\text { This may be due to } \\
\text { transferring to an OAMH } \\
\text { specialised team. } \\
\text { Patients also more likely to } \\
\text { go into care homes which } \\
\text { are not equipped to manage } \\
\text { the illness. }\end{array}$ & Not discussed & $\begin{array}{l}\text { There is unmet need in } \\
\text { clinical needs and social } \\
\text { needs. The writer suggests } \\
\text { this may be because people } \\
\text { are transferred to older adult } \\
\text { services upon } 65 \text {. } \\
\text { Care homes were better } \\
\text { equipped } \\
\text { to manage those with } \\
\text { dementia rather than } \\
\text { functional mental illness. } \\
\text { Limitations: } \\
\text { Local area findings may } \\
\text { make findings difficult to } \\
\text { generalise. } \\
\text { Approximately a quarter of } \\
\text { the available group did not } \\
\text { participate. }\end{array}$ & $\begin{array}{l}\text { CASP } \\
8 / 10\end{array}$ \\
\hline $\begin{array}{l}\text { Molyneux et } \\
\text { al. (2008) } \\
\text { Ireland }\end{array}$ & $\begin{array}{l}\text { Quantitative } \\
\text { Cross sectional } \\
\text { study }\end{array}$ & $\begin{array}{l}\text { This study assessed the prevalence } \\
\text { of depression, the level of carer } \\
\text { burden/strain, and the problems } \\
\text { experienced by the carers of patients } \\
\text { referred to Psychiatry of Old Age } \\
\text { Service. }\end{array}$ & $\begin{array}{l}\text { Carers of people } \\
\text { referred to an } \\
\text { OAMH service } \\
(n=100) \\
\text { Community }\end{array}$ & $\begin{array}{l}\text { Spouses had less identified } \\
\text { need and burden, } \\
\text { hypothesis for this is it is } \\
\text { expected of their role to } \\
\text { care for their spouse. }\end{array}$ & Not discussed & $\begin{array}{l}\text { Patient's diagnosis did not } \\
\text { affect carer strain; carers } \\
\text { who cared for people with } \\
\text { depression experienced the } \\
\text { same amount carer burden. } \\
\text { Many carers caring for a } \\
\text { person are also depressed. } \\
\text { Limitations: }\end{array}$ & $\begin{array}{l}\text { NIHLB } \\
\text { Yes to all } \\
\text { questions }\end{array}$ \\
\hline
\end{tabular}




\begin{tabular}{|c|c|c|c|c|c|c|c|}
\hline $\begin{array}{l}\text { Author, year } \\
\& \text { Country }\end{array}$ & $\begin{array}{l}\text { Study design, data } \\
\text { collection and } \\
\text { method }\end{array}$ & Aim of the study & $\begin{array}{l}\text { Participant } \\
\text { characteristics / } \\
\text { sample size/ } \\
\text { setting }\end{array}$ & $\begin{array}{l}\text { Research Question } \\
\text { What are the experiences } \\
\text { of key stakeholders in } \\
\text { relation to mental health } \\
\text { services? }\end{array}$ & $\begin{array}{l}\text { Research Question } \\
\text { What are key stakeholders' } \\
\text { experiences in relation to } \\
\text { accessibility and availability } \\
\text { of mental health services? }\end{array}$ & Key findings & $\begin{array}{l}\text { Quality } \\
\text { Appraisal }\end{array}$ \\
\hline & & & & & & $\begin{array}{l}\text { The use of the Geriatric } \\
\text { Depression Scale may not } \\
\text { reveal the severity of } \\
\text { depressive symptoms. } \\
\text { Low sample group in each } \\
\text { illness domain. }\end{array}$ & \\
\hline $\begin{array}{l}\text { Morrow- } \\
\text { Howell et al. } \\
(2000) \\
\text { USA }\end{array}$ & $\begin{array}{l}\text { Quantitative } \\
\text { Data from } \\
\text { medical records } \\
\text { collected }\end{array}$ & $\begin{array}{l}\text { This study explores need to reflect a } \\
\text { bio psychosocial approach to mental } \\
\text { illness including mental, } \\
\text { psychosocial and functional need. }\end{array}$ & $\begin{array}{l}\text { Older people } \\
\text { hospitalised with } \\
\text { depression } \\
(n=169) \text { Post } \\
\text { acute care }\end{array}$ & $\begin{array}{l}\text { Unmet physical and } \\
\text { psychosocial need affect } \\
\text { the mental health outcome } \\
\text { of carers }\end{array}$ & Not discussed & $\begin{array}{l}\text { Older adults admitted to } \\
\text { hospital for depression have } \\
\text { extraordinary levels of need } \\
\text { across the domains of a bio } \\
\text { psychosocial model. } \\
\text { This illustrates the } \\
\text { complexities of older adults } \\
\text { in terms of experiencing } \\
\text { physical illness at the same } \\
\text { time as mental illness }\end{array}$ & CASP $8 / 10$ \\
\hline $\begin{array}{l}\text { Muir et al. } \\
\text { (2014) } \\
\text { Australia }\end{array}$ & $\begin{array}{l}\text { Qualitative } \\
\text { Semi structured } \\
\text { interviews }\end{array}$ & $\begin{array}{l}\text { This study explored the views of } \\
\text { health and social care providers of } \\
\text { the barriers to effective mental } \\
\text { health care for older people } \\
\text { in a rural region. }\end{array}$ & $\begin{array}{l}\text { Older people } \\
\text { aged } 65 \text { and over } \\
(n=19) \\
\text { Community }\end{array}$ & $\begin{array}{l}\text { Older people showed } \\
\text { reluctance in recognising } \\
\text { they had a need for help. } \\
\text { Carers focused on the } \\
\text { needs of the person and } \\
\text { neglected themselves. }\end{array}$ & $\begin{array}{l}\text { Participants felt services } \\
\text { were not available and had } \\
\text { difficulties getting } \\
\text { appointments with their } \\
\text { physician and mental health } \\
\text { services. } \\
\text { There was a feeling mental } \\
\text { health services were } \\
\text { stretched and therefore there } \\
\text { was no capacity when people } \\
\text { needed them. } \\
\text { Transport posed a difficulty } \\
\text { to frailer people. }\end{array}$ & $\begin{array}{l}\text { Older people are not } \\
\text { accessing services for } \\
\text { reason's including: } \\
\text { ageism, } \\
\text { lack of appropriate service, } \\
\text { fear of loss of independence } \\
\text { and } \\
\text { Financial constraints. } \\
\text { There is a perception from } \\
\text { professionals that } \\
\text { Depression is a natural part } \\
\text { of aging. } \\
\text { Limitations: }\end{array}$ & $\begin{array}{l}\text { CASP } \\
9 / 10\end{array}$ \\
\hline
\end{tabular}




\begin{tabular}{|c|c|c|c|c|c|c|c|}
\hline $\begin{array}{l}\text { Author, year } \\
\& \text { Country }\end{array}$ & $\begin{array}{l}\text { Study design, data } \\
\text { collection and } \\
\text { method }\end{array}$ & Aim of the study & $\begin{array}{l}\text { Participant } \\
\text { characteristics / } \\
\text { sample size/ } \\
\text { setting }\end{array}$ & $\begin{array}{l}\text { Research Question } \\
\text { What are the experiences } \\
\text { of key stakeholders in } \\
\text { relation to mental health } \\
\text { services? }\end{array}$ & $\begin{array}{l}\text { Research Question } \\
\text { What are key stakeholders' } \\
\text { experiences in relation to } \\
\text { accessibility and availability } \\
\text { of mental health services? }\end{array}$ & Key findings & $\begin{array}{l}\text { Quality } \\
\text { Appraisal }\end{array}$ \\
\hline & & & & & $\begin{array}{l}\text { Having to go via a physician } \\
\text { to access referral to specialist } \\
\text { service was seen as a barrier }\end{array}$ & $\begin{array}{l}\text { Recruitment area very } \\
\text { specific in geographical area. } \\
\text { Illness types not defined. }\end{array}$ & \\
\hline $\begin{array}{l}\text { Nelson and } \\
\text { Park (2006) } \\
\text { Canada }\end{array}$ & $\begin{array}{l}\text { Quantitative } \\
\text { Survey }\end{array}$ & $\begin{array}{l}\text { This study was to shed light on the } \\
\text { magnitude and underlying reasons } \\
\text { for perceived unmet mental health } \\
\text { needs and their relation to gender } \\
\text { and age. }\end{array}$ & $\begin{array}{l}\text { People using } \\
\text { mental health } \\
\text { services across } \\
\text { all age spans } \\
(n=13,814) \\
\text {. } \\
\text { People aged } 65 \\
\text { and over } \\
(n=2752) \\
\text { Community } \\
\text { Health Services }\end{array}$ & $\begin{array}{l}\text { Younger age groups } \\
\text { reported more unmet need } \\
\text { than older people. Because } \\
\text { older people were more } \\
\text { accepting of their need. } \\
\text { Younger adults were more } \\
\text { likely to report barriers to } \\
\text { accessing services, } \\
\text { including cost and lack of } \\
\text { transport }\end{array}$ & Not discussed & $\begin{array}{l}\text { People over } 65 \text { are eight } \\
\text { times less likely to have } \\
\text { unmet need compared to } 15- \\
24 \text { year olds. However, the } \\
\text { study did not explore if older } \\
\text { people had a perceived need. } \\
\text { Limitations: } \\
\text { Perceived need was not } \\
\text { explored which may skew } \\
\text { findings }\end{array}$ & $\begin{array}{l}\text { CASP } \\
8 / 10\end{array}$ \\
\hline $\begin{array}{l}\text { Palinkas et al. } \\
(2007) \\
\text { USA }\end{array}$ & $\begin{array}{l}\text { Qualitative } \\
\text { Semi-structured } \\
\text { interviews }\end{array}$ & $\begin{array}{l}\text { To explore unmet need in older } \\
\text { adults with mental illness in } \\
\text { San Diego. }\end{array}$ & \begin{tabular}{|l} 
Phase 1: \\
Care providers \\
$(n=23)$ \\
Older people \\
$(n=16)$ \\
Care givers \\
$(n=19)$ \\
Phase 2: \\
Care providers \\
$(n=18)$ \\
Older people \\
$(n=50)$ \\
Caregivers \\
$(n=39)$
\end{tabular} & $\begin{array}{l}\text { Many older people will not } \\
\text { access services for fear of } \\
\text { stigma of losing their } \\
\text { independence. } \\
\text { A lack of understanding of } \\
\text { older people's needs was } \\
\text { felt along with an ageist } \\
\text { attitude. } \\
\text { Depression is viewed as a } \\
\text { natural part of aging. } \\
\text { There is a lack of resource } \\
\text { for care givers of older } \\
\text { adults. }\end{array}$ & $\begin{array}{l}\text { A lack of accessibility of age } \\
\text { appropriate services, older } \\
\text { people don't fit into general } \\
\text { services. } \\
\text { Lack of information on } \\
\text { follow up. } \\
\text { Financial constraints if } \\
\text { people do not have } \\
\text { insurance. } \\
\text { Lack of affordable } \\
\text { transportation. }\end{array}$ & $\begin{array}{l}\text { Older people are not } \\
\text { accessing services for } \\
\text { reason's including: } \\
\text { ageism, } \\
\text { lack of appropriate service, } \\
\text { fear of loss of independence } \\
\text { and } \\
\text { Financial constraints. } \\
\text { There is a perception from } \\
\text { professionals that } \\
\text { Depression is a natural part } \\
\text { of aging. } \\
\text { Limitations: } \\
\text { Recruitment area very } \\
\text { specific in geographical area. }\end{array}$ & $\begin{array}{l}\text { CASP } \\
8 / 10\end{array}$ \\
\hline
\end{tabular}




\begin{tabular}{|c|c|c|c|c|c|c|c|}
\hline $\begin{array}{l}\text { Author, year } \\
\& \text { Country }\end{array}$ & $\begin{array}{l}\text { Study design, data } \\
\text { collection and } \\
\text { method }\end{array}$ & Aim of the study & $\begin{array}{l}\text { Participant } \\
\text { characteristics / } \\
\text { sample size/ } \\
\text { setting }\end{array}$ & $\begin{array}{l}\text { Research Question } \\
\text { What are the experiences } \\
\text { of key stakeholders in } \\
\text { relation to mental health } \\
\text { services? }\end{array}$ & $\begin{array}{l}\text { Research Question } \\
\text { What are key stakeholders' } \\
\text { experiences in relation to } \\
\text { accessibility and availability } \\
\text { of mental health services? }\end{array}$ & Key findings & $\begin{array}{l}\text { Quality } \\
\text { Appraisal }\end{array}$ \\
\hline & & & & & & Illness types not defined. & \\
\hline $\begin{array}{l}\text { Preville et al. } \\
(2009) \\
\text { Canada }\end{array}$ & $\begin{array}{l}\text { Quantitative } \\
\text { (Cross } \\
\text { sectional study) } \\
\\
\text { survey }\end{array}$ & $\begin{array}{l}\text { To document the use of mental } \\
\text { health services by older people in } \\
\text { Quebec and } \\
\text { any unmet need. }\end{array}$ & $\begin{array}{l}\begin{array}{l}\text { Older people } \\
(n=2784)\end{array} \\
\text { Community } \\
\text { setting }\end{array}$ & Not discussed & $\begin{array}{l}\text { Those living in urban or rural } \\
\text { area more likely to seek help } \\
\text { than people from the inner } \\
\text { city. } \\
\text { Most sought help via a } \\
\text { physician who referred onto } \\
\text { specialist service. } \\
\text { Unmarried people more } \\
\text { likely to seek services. } \\
57 \% \text { of people who would } \\
\text { have met a Diagnostic } \\
\text { Statistical Manual V } \\
\text { diagnosis did not seek help } \\
\text { from services. }\end{array}$ & $\begin{array}{l}57 \% \text { of older people who } \\
\text { meet diagnostic criteria for } \\
\text { mental illness are not } \\
\text { seeking the help they need } \\
\text { and therefore there is } \\
\text { significant unmet need in } \\
\text { this population. } \\
\text { Limitations: } \\
\text { Findings were self reported } \\
\text { and therefore may be biased } \\
\text { regarding the patients } \\
\text { attitude at the time of the } \\
\text { study. }\end{array}$ & $\begin{array}{l}\text { CASP } \\
10 / 10\end{array}$ \\
\hline $\begin{array}{l}\text { Robb et al. } \\
(2003) \\
\text { USA }\end{array}$ & $\begin{array}{l}\text { Quantitative } \\
\text { Survey }\end{array}$ & $\begin{array}{l}\text { To explore older people's perception } \\
\text { of mental health care in comparison } \\
\text { to younger people. }\end{array}$ & \begin{tabular}{|l}
$\begin{array}{l}\text { Adults aged } 65 \\
\text { and over } \\
(n=474)\end{array}$ \\
Adults aged \\
$<65(n=1001)$ \\
\\
Community \\
setting
\end{tabular} & $\begin{array}{l}\text { No difference in } \\
\text { satisfaction scores between } \\
\text { younger and older adults in } \\
\text { relation to mental health } \\
\text { services. } \\
\text { Older people were less } \\
\text { knowledgeable about the } \\
\text { services available. } \\
\text { Younger people were more } \\
\text { open to the idea that they } \\
\text { need to do things to } \\
\text { improve their own mental } \\
\text { health. }\end{array}$ & $\begin{array}{l}\text { Younger people almost twice } \\
\text { as likely to have seen a } \\
\text { mental health practitioner. } \\
\text { Younger people stated they } \\
\text { had better access compared } \\
\text { to older people. } \\
\text { Lack of insurance and cost } \\
\text { both seen as barriers to } \\
\text { accessing services in both } \\
\text { age groups. }\end{array}$ & $\begin{array}{l}\text { Older adults less likely to } \\
\text { use services than younger } \\
\text { people. } \\
\text { Older adults less confident in } \\
\text { their knowledge about } \\
\text { services available. } \\
\text { Older adults less likely to } \\
\text { have insurance coverage. } \\
\text { Limitations } \\
\text { The older population were } \\
\text { affluent and well educated } \\
\text { which may not be true of a } \\
\text { more generlaised population. }\end{array}$ & $\begin{array}{l}\text { CASP } \\
10 / 10\end{array}$ \\
\hline
\end{tabular}




\begin{tabular}{|c|c|c|c|c|c|c|c|}
\hline $\begin{array}{l}\text { Author, year } \\
\& \text { Country }\end{array}$ & $\begin{array}{l}\text { Study design, data } \\
\text { collection and } \\
\text { method }\end{array}$ & Aim of the study & \begin{tabular}{|l} 
Participant \\
characteristics / \\
sample size/ \\
setting
\end{tabular} & $\begin{array}{l}\text { Research Question } \\
\text { What are the experiences } \\
\text { of key stakeholders in } \\
\text { relation to mental health } \\
\text { services? }\end{array}$ & $\begin{array}{l}\text { Research Question } \\
\text { What are key stakeholders' } \\
\text { experiences in relation to } \\
\text { accessibility and availability } \\
\text { of mental health services? }\end{array}$ & Key findings & $\begin{array}{l}\text { Quality } \\
\text { Appraisal }\end{array}$ \\
\hline $\begin{array}{l}\text { Sarkin etal. } \\
\text { (2015) } \\
\text { USA }\end{array}$ & $\begin{array}{l}\text { Quantitative } \\
\text { Survey }\end{array}$ & $\begin{array}{l}\text { The study explores how age, gender } \\
\text { and ethnicity and mental health } \\
\text { diagnosis contribute to stigma for } \\
\text { those using mental health services. }\end{array}$ & $\begin{array}{l}\begin{array}{l}\text { People with FMI } \\
(n=1237)\end{array} \\
\text { Community }\end{array}$ & $\begin{array}{l}\text { As age increased people } \\
\text { felt less discriminated } \\
\text { against. } \\
\text { This was only a marginal } \\
\text { finding with younger } \\
\text { people perceiving they } \\
\text { experienced more } \\
\text { discrimination. }\end{array}$ & Not discussed & $\begin{array}{l}\text { Older people experienced } \\
\text { marginally less stigma. } \\
\text { Limitations: } \\
\begin{array}{l}\text { Age breakdown findings are } \\
\text { only discussed generally }\end{array}\end{array}$ & $\begin{array}{l}\text { NIHLB } \\
\text { Yes all } \\
\text { questions }\end{array}$ \\
\hline $\begin{array}{l}\text { Simning et al. } \\
(2010) \\
\text { USA }\end{array}$ & $\begin{array}{l}\text { Quantitative } \\
\text { Interviews to } \\
\text { collect data on } \\
\text { Goldberg Anxiety } \\
\text { Scale, The Patient } \\
\text { Health } \\
\text { Questionnaire, } \\
\text { and Service } \\
\text { utilisation }\end{array}$ & $\begin{array}{l}\text { To explore mental distress of and } \\
\text { help seeking utilisation of older } \\
\text { people in a community setting. }\end{array}$ & 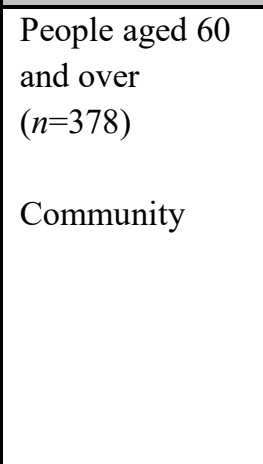 & $\begin{array}{l}\text { Individuals who were } \\
\text { distressed used more than } \\
\text { one service. } \\
\text { Likelihood of a distressed } \\
\text { individual seeing a mental } \\
\text { health professional was } \\
\text { significantly higher than a } \\
\text { non distressed individual. }\end{array}$ & Not discussed & $\begin{array}{l}\text { People who were distressed } \\
\text { had more contact with } \\
\text { services, and therefore may } \\
\text { be effective at reducing } \\
\text { admission. } \\
\text { Limitations: } \\
\text { Participants were from a } \\
\text { single area and the findings } \\
\text { cannot be generalise. }\end{array}$ & $\begin{array}{l}\text { CASP } \\
10 / 10\end{array}$ \\
\hline
\end{tabular}

